UNIVERSIDADE ESTADUAL PAULISTA “JÚLIO DE MESQUITA FILHO” FACULDADE DE CIÊNCIAS AGRONÔMICAS CAMPUS DE BOTUCATU

\title{
MARCHA DE ABSORÇÃO DE MACRONUTRIENTES E ACÚMULO DE FENÓLICOS TOTAIS EM [BACCHARIS TRIMERA (LESS.) DC.] VAR. CPQBA-1, SOB DIFERENTES PODAS NO PLANTIO.
}

\section{MAURÍCIO AUGUSTO ANDRIÃO}


UNIVERSIDADE ESTADUAL PAULISTA “JÚLIO DE MESQUITA FILHO” FACULDADE DE CIÊNCIAS AGRONÔMICAS CAMPUS DE BOTUCATU

\title{
MARCHA DE ABSORÇÃO DE MACRONUTRIENTES E ACÚMULO DE FENÓLICOS TOTAIS EM [BACCHARIS TRIMERA (LESS.) DC.] VAR. CPQBA-1, SOB DIFERENTES PODAS NO PLANTIO.
}

\author{
MAURÍCIO AUGUSTO ANDRIÃO \\ Orientador: Prof. Dr. Luis Vitor Silva do Sacramento \\ Dissertação apresentada à Faculdade de Ciências \\ Agronômicas da Unesp - Campus de Botucatu, \\ para a obtenção do título de Mestre em \\ Agronomia - Área de Concentração em \\ Horticultura.
}

BOTUCATU-SP

Março - 2010 
FICHA CATALOGRÁFICA ELABORADA PELA SEÇÃO TÉCNICA DE AQUISIÇÃO E TRATAMENTO DA INFORMAÇÃO SERVIÇO TÉCNICO DE BIBLIOTECA E DOCUMENTAÇÃO - UNESP - FCA

- LAGEADO - BOTUCATU (SP)

Andrião, Maurício Augusto, 1983-

A573m Marcha de absorção de macronutrientes e acúmulo de fenólicos totais em [Baccharis trimera (Less.) DC.] var.

CPQBA-1, sob diferentes podas no plantio / Maurício Augus-

to Andrião. - Botucatu : [s.n.], 2010.

ix, 65 f. : il. color., gráfs., tabs.

Dissertação (mestrado) - Universidade Estadual Paulis-

ta, Faculdade de Ciências Agronômicas, Botucatu, 2010

Orientador: Luis Vitor Silva do Sacramento

Inclui bibliografia.

1. Carqueja. 2. Fenóis. 3. Plantas medicinais. 4. Nutrição mineral. 5. Baccharis trimera. 6. Marcha de absorcão. I. Sacramento, Luis Vitor Silva do. II. Uiversidade Estadual Paulista "Júlio de Mesquita Filho" Campus de Botucatu). Faculdade de Ciências Agronômicas. III. Título. 
UNIVERSIDADE ESTADUAL PAULISTA "JÚLIO DE MESQUITA FILHO" FACULDADE DE CIÊNCIAS AGRONÔMICAS

CAMPUS DE BOTUCATU

CERTIFICADO DE APROVAÇĀO

TITULO: "MARCHA DE ABSORÇÃO DE MACRONUTRIENTES E ACÚMULO DE FENÓLICOS TOTAIS EM [Baccharis trimera (Less.) DC.] var. CPQBA-1, SOB DIFERENTES PODAS DE PLANTIO"

ALUNO: MAURÍCIO AUGUSTO ANDRIÃO

ORIENTADOR: PROF. DR. LUIS VITOR SILVA DO SACRAMNTO

Aprovado pela Comissão Examinadora
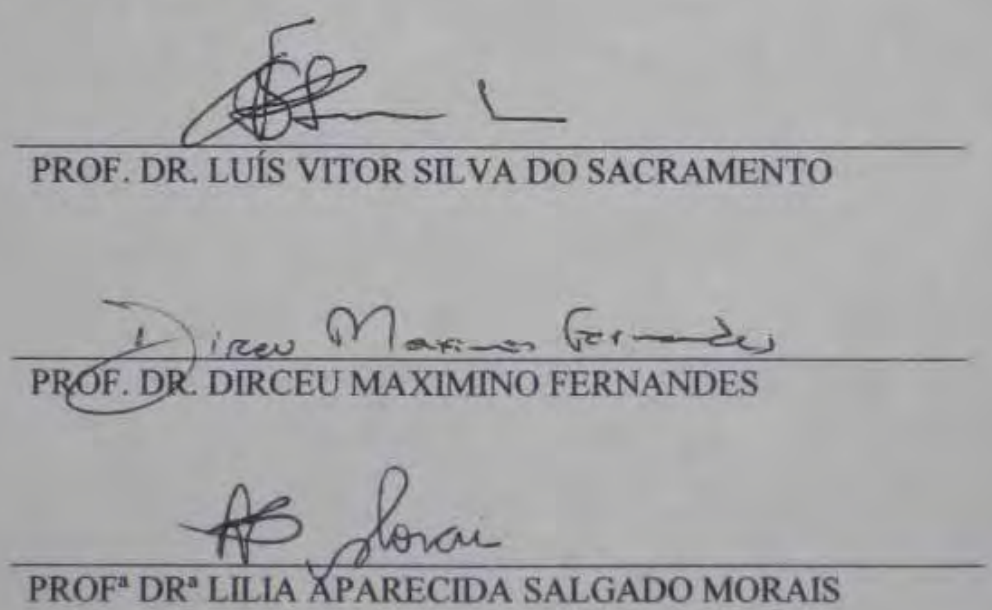

Data da Realização: 30 de Março de 2010. 
“...naquela época,

quando tomava picada de cobra,

nóis levava pra ele,

que fazia um benzimento, ponhava umas ervas e logo saráva! '

Sr. Francisco Pereira, 2010. 
Aos que ainda respeitam as limitações do Ser Humano! 


\section{AGRADECIMENTOS}

À Faculdade de Ciências Agronômicas - UNESP, Campus de Botucatu, pela completa estrutura fornecida à minha formação no mestrado.

À Faculdade de Ciências Farmacêuticas - UNESP, Campus de Araraquara, por ter propiciado condições para realização deste trabalho (Horto de Plantas Medicinais e Tóxicas do Departamento de Princípios Ativos Naturais e Toxicologia e Laboratório de Botânica.

Ao Setor de Agrotecnologia do Centro de Pluridisciplinar de Pesquisas Químicas, Biológicas e Agrícolas da UNICAMP, na pessoa do pesquisador Ílio Montanari Júnior pela doação do material propagativo e elaboração das mudas.

Ao CNPQ, pela concessão da bolsa de estudos.

Ao grande Mestre orientador Prof. Dr. Luis Vitor Silva do Sacramento, pelos conhecimentos transmitidos e pelo exemplo de Ser Humano.

À minha família em especial meus pais (Osni e Bete), pelo alicerce emocional, pelo incentivo e pelo Amor eterno!

Ao meu irmão, por indiretamente ter colaborado para eu ser quem sou hoje!

Aos meus amigos universitários por toda ajuda prestada e principalmente pelo companheirismo e alegria (Camila, Fátima, Letícia, Humberto, Emi, Danila). Em especial aos colegas de república em Botucatu (Sérgio Marques, o Mineiro; Efrain Santana, o Berinjela; Rony; Sasso e Chrystian, o Xirú). Aos amigos da república em Araraquara (Antônio, o Farinha, Guilherme e Rudy).

Ao amigos conquistados no Laboratório de Botânica do Departamento de Princípios Ativos Naturais e Toxicologia da Faculdade de Ciências Farmacêuticas da UNESP, Campus de Araraquara (LBOT): Andréa, Juninho, Super, Luis Antônio e Angélica.

Aos estagiários do LBOT pelo empenho em busca do conhecimento, em especial, ao grande amigo Henrique Toloi, o Velinho, à Sheila e ao Bruno.

Ao Alexandre Stucchi (Frankstein) FCAV-UNESP pela ajuda na implantação do experimento. 
Aos colegas profissionais que acompanharam parte desta batalha: Luiz Arthur e Luiz Gonzaga Cury e Silva (Humânita S/A), Ademar Menezes Jr. (Oficina de Ervas) e Everaldo Eller (Tecnutri do Brasil).

Aos amigos de Ribeirão Preto, grandes Magos, vocês são parte do meu existir!

À minha namorada Fernanda Pereira, pelo equilíbrio, pela força, pela paciência, pelos conhecimentos e tempo cedidos, pelo indescritível AMOR.

Ao Prof. Dr. Lin Chau Ming, pelas instruções de qual caminho trilhar, e pelo exemplo profissional.

Ao Prof. Dr. Roberto Lyra Villas Boas, pelo dedicação ao ensino e pela seriedade científica, desprovida de preconceitos!

Aos Professores Doutores Carmen Silvia Fernandes Boaro e Dirceu Maximino Fernandes, pela didática nos ensinamentos, pelo apoio e comprometimento científico.

Ao Prof. Dr. André Gonzaga dos Santos, do Laboratório de Farmacognosia da FCF/UNESP pelas recomendações nas análises dos teores de fenólicos totais.

Às funcionárias da Seção de Pós-Graduação e da Biblioteca da FCA/UNESP, pela simpatia e por toda atenção que sempre me dedicaram. 


\section{SUMÁRIO}

Página

LISTA DE TABELAS............................................................................. VII

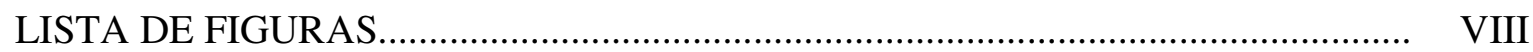

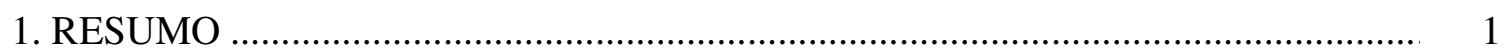

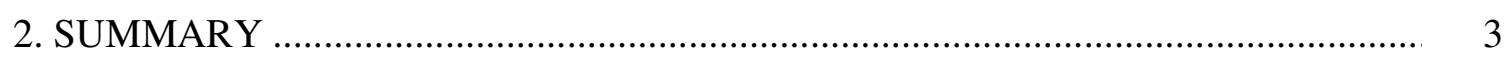

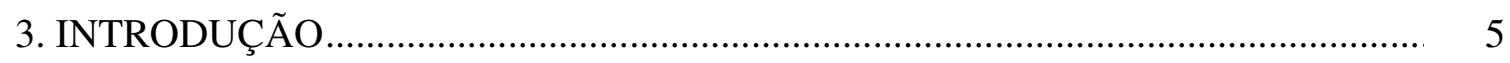

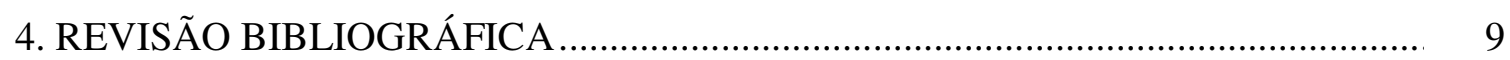

4.1. Aspectos botânicos de Baccharis trimera (Less.) DC................................... 9

4.2. Aspectos ambientais de B. trimera ................................................................ $\quad 10$

4.3. Aspectos farmacológicos e fitoquímicos de B. trimera................................... 11

4.4. Aspectos sócio-econômicos de B. trimera ........................................................ 13

4.5. Aspectos agronômicos de B. trimera.............................................................. 16

5. MATERIAL E MÉTODOS _............................................................................... 20

5.1. Caracterização da espécie e variedade............................................................... 20

5.2. Obtenção do material botânico e formação das mudas.................................... 21

5.3. Caracterização da área experimental............................................................ 21

5.4. Delineamento estatístico............................................................................. 21

5.5. Instalação e condução do experimento ......................................................... 21

5.6. Variáveis analisadas................................................................................. 25

5.6.1. Matéria Seca …................................................................................ 25

5.6.2. Acúmulo de macronutrientes................................................................ 25

5.6.3. Determinação do teor e acúmulo de fenólicos totais................................ 25

5.3.3.1. Obtenção dos extratos ............................................................. 26

5.3.3.2 Curva padrão e doseamento dos fenólicos totais............................ 26

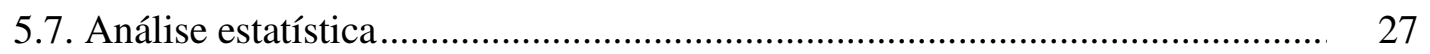

6. RESULTADOS E DISCUSSÃO ……............................................................... 28

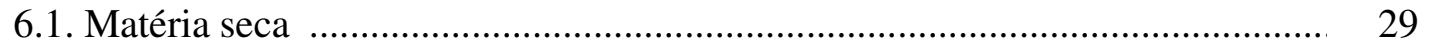

6.2. Marcha de absorção de macronutrientes .......................................................... 31 
6.2.1. Nitrogênio......................................................................................... 33

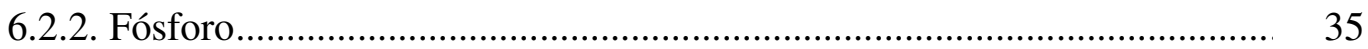

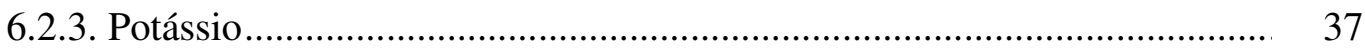

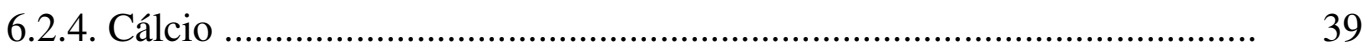

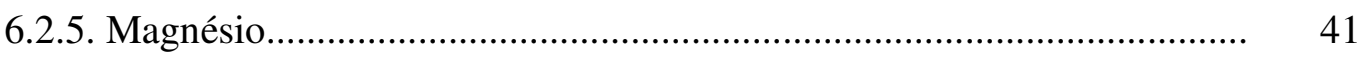

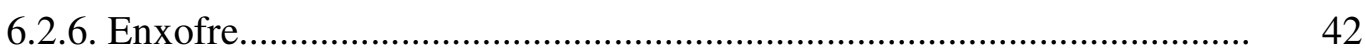

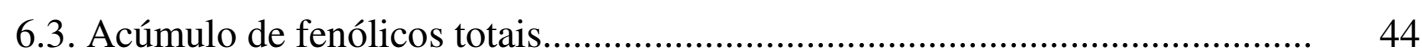

6.4. Análise conjunta entre os diferentes manejos............................................... 46

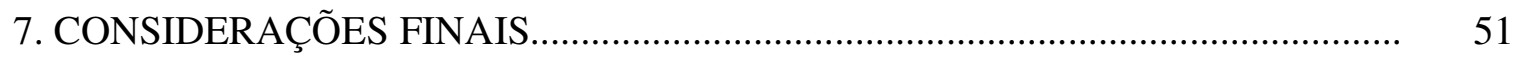

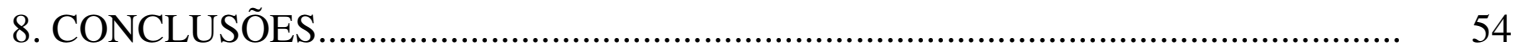

9. REFERÊNCIAS BIBLIOGRÁFICAS................................................................ 56 


\section{LISTA DE TABELAS}

Tabela

Página

1 Análise das características do solo do Horto de Plantas Medicinais e Tóxicas do Departamento de Princípios Ativos Naturais e Toxicologia da FCF/UNESP, antes da implantação do experimento. Araraquara, SP, 2009

2 Análise das características do esterco bovino. Botucatu, SP, 2009.......

3 Produção média de matéria seca da parte aérea e raízes de carqueja cultivada sob dois sistemas de cultivo, com e sem poda no dia de transplantio. Araraquara, SP, 2009

4 Teores de macronutrientes em partes aéreas de plantas de carqueja var. CPQBA-1 cultivadas em vasos em casa de vegetação durante 150 dias, sem poda no dia de transplantio. Araraquara, SP, 2009 .

5 Teores de macronutrientes em raízes de plantas de carqueja var. CPQBA-1 cultivadas em vasos em casa de vegetação durante 150 dias, sem poda no dia de transplantio. Araraquara, SP, 2009 .....

6 Teores de macronutrientes em partes aéreas de plantas de carqueja var. CPQBA-1 cultivadas em vasos em casa de vegetação durante 150 dias, com poda no dia de transplantio. Araraquara, SP, 2009

7 Teores de macronutrientes em raízes de plantas de carqueja var. CPQBA-1 cultivadas em vasos em casa de vegetação durante 150 dias, com poda no dia de transplantio. Araraquara, SP, 2009

8 Teores de compostos fenólicos totais em partes aéreas de plantas de carqueja var. CPQBA-1 cultivadas em vasos em casa de vegetação durante 150 dias, sem e com poda no dia de transplantio. Araraquara, SP, 2009

9 Análise conjunta entre os dois experimentos, com e sem poda no dia do transplantio de carqueja var. CPQBA-1 cultivadas em vasos em casa de vegetação durante 150 dias, sem e com poda no dia de transplantio. Araraquara, SP, 2009 


\section{LISTA DE FIGURAS}

Figura

Página

1 Disposição dos vasos de plantas de carqueja var. CPQBA-1 cultivadas em casa de vegetação do Horto de Plantas Medicinais e Tóxicas do Departamento de Princípios Ativos Naturais e Toxicologia da FCF/UNESP. Araraquara, SP, 2009

2 Tratamento de manejo: Mudas de carqueja var. CPQBA-1 com poda à partir de $15 \mathrm{~cm}$ do solo no dia do transplantio e sem poda no dia do transplantio. Horto da FCF/UNESP. Araraquara, SP, 2009

Curva de regressão para soluções de ácido gálico empregadas como padrão de referência na determinação de compostos fenólicos totais....

4 Produção de matéria seca de plantas de carqueja var. CPQBA-1 cultivadas em vasos em casa de vegetação durante 150 dias. (A): Parte aérea - sem poda no transplantio; (B): Parte aérea - com poda no transplantio; (C) Raiz - sem poda no transplantio; (D) Raiz - com poda no transplantio. FCF/UNESP. Araraquara, SP, 2009.*médias transformadas $(\sqrt{ } \mathrm{x}+\mathrm{y})$.

5 Acúmulo de nitrogênio em plantas de carqueja var. CPQBA-1 cultivadas em vasos em casa de vegetação durante 150 dias. (A): Parte aérea - sem poda no transplantio; (B): Parte aérea - com poda no transplantio; (C) Raiz - sem poda no transplantio; (D) Raiz - com poda no transplantio. FCF/UNESP. Araraquara, SP, 2009.

6 Acúmulo de fósforo em plantas de carqueja var. CPQBA-1 cultivadas em vasos em casa de vegetação durante 150 dias. (A): Parte aérea sem poda no transplantio; (B): Parte aérea - com poda no transplantio; (C) Raiz - sem poda no transplantio; (D) Raiz - com poda no transplantio. FCF/UNESP. Araraquara, SP, 2009.

7 Acúmulo de potássio em plantas de carqueja var. CPQBA-1 cultivadas em vasos em casa de vegetação durante 150 dias. (A): Parte aérea - sem poda no transplantio; (B): Parte aérea - com poda no transplantio; (C) Raiz - sem poda no transplantio; (D) Raiz - com poda no transplantio. FCF/UNESP. Araraquara, SP, 2009.

8 Acúmulo de cálcio em plantas de carqueja var. CPQBA-1 cultivadas em vasos em casa de vegetação durante 150 dias. (A): Parte aérea sem poda no transplantio; (B): Parte aérea - com poda no transplantio; (C) Raiz - sem poda no transplantio; (D) Raiz - com poda no transplantio. FCF/UNESP. Araraquara, SP, 2009. 
9 Descoloração das alas foliares de carqueja var. CPQBA-1 cultivada em vaso em casa de vegetação. FCF/UNESP. Araraquara, SP, 2009 .

10 Acúmulo de magnésio em plantas de carqueja var. CPQBA-1 cultivadas em vasos em casa de vegetação durante 150 dias. (A): Parte aérea - sem poda no transplantio; (B): Parte aérea - com poda no transplantio; (C) Raiz - sem poda no transplantio; (D) Raiz - com poda no transplantio. FCF/UNESP. Araraquara, SP, 2009.

11 Acúmulo de enxofre em plantas de carqueja var. CPQBA-1 cultivadas em vasos em casa de vegetação durante 150 dias. (A): Parte aérea sem poda no transplantio; (B): Parte aérea - com poda no transplantio; (C) Raiz - sem poda no transplantio; (D) Raiz - com poda no transplantio. FCF/UNESP. Araraquara, SP, 2009.

12 Acúmulo de compostos fenólicos totais em plantas de carqueja var. CPQBA-1 cultivadas em vasos em casa de vegetação durante 150 dias. (A): Parte aérea - sem poda no transplantio; (B): Parte aérea com poda no transplantio. FCF/UNESP. Araraquara, SP, 2009

13 Acúmulo de macronutrientes, compostos fenólicos totais e produção de matéria seca em partes aéreas de plantas de carqueja var. CPQBA1 cultivadas em vasos em casa de vegetação durante 150 dias. (A): Sem poda no transplantio; (B): Com poda no transplantio. FCF/UNESP. Araraquara, SP, 2009

14 Acúmulo de macronutrientes, compostos fenólicos totais e produção de matéria seca em raízes de plantas de carqueja var. CPQBA-1 cultivadas em vasos em casa de vegetação durante 150 dias. (A): Sem poda no transplantio; (B): Com poda no transplantio. FCF/UNESP. Araraquara, SP, 2009 


\section{RESUMO}

O objetivo deste trabalho foi conhecer a marcha de absorção de macronutrientes em Baccharis trimera (Less.) DC. var. CPQBA-1, bem como verificar o acúmulo e o teor de fenólicos totais em função do tempo. As mudas foram obtidas a partir de sementes de matrizes do CPQBA/UNICAMP e transplantadas para vasos no início do experimento em casa de vegetação. Para o delineamento estatístico optou-se pela metodologia de grupos de experimentos, neste caso dois experimentos com a mesma estrutura, variando-se apenas o manejo no dia do transplantio, que constou de uma poda executada a $15 \mathrm{~cm}$ a partir do solo para um dos grupos. O delineamento experimental em blocos casualizados, considerou cinco épocas de amostragem em intervalos de 30 dias durante 150 dias e quatro repetições, perfazendo-se um total de 20 parcelas, cada qual composta por dois vasos com duas plantas em cada vaso. No total, foram consideradas 40 unidades experimentais. $\mathrm{O}$ material fresco obtido em cada amostragem foi conduzido à secagem em estufa, triturado e submetido às análises. Avaliaram-se as partes aéreas e raízes quanto à massa da matéria seca, teor e acúmulo de macronutrientes e de fenólicos totais. Realizou-se a análise conjunta dos dois experimentos para os níveis do fator qualitativo (manejo), considerando-se as variáveis 
produção de matéria seca da parte aérea e raízes e acúmulo de fenólicos totais. Os valores obtidos para as variáveis observadas foram submetidos à análise de variância e análise de regressão para as épocas de amostragem considerando o nível de 5\% de probabilidade. A produção de matéria seca foi ascendente durante todo o ciclo, demonstrando crescimento abundante a partir dos 90 de cultivo, seguido de estabilização nos últimos 30 dias de cultivo. Os sistemas de manejo não influenciaram a produção de matéria seca das partes aéreas e raízes, nem a produção de compostos fenólicos totais. $\mathrm{O}$ acúmulo de fenólicos mostrou-se ascendente atingido o pico de produção aos 150 dias de cultivo. A ordem de acúmulo de macronutrientes após 150 dias de cultivo, nas plantas que não receberam a poda foi $\mathrm{K}>\mathrm{N}>$ $\mathrm{Ca}>\mathrm{P}>\mathrm{Mg}>\mathrm{S}$ e nas que receberam a poda foi $\mathrm{K}>\mathrm{Ca}>\mathrm{P}>\mathrm{Mg}>\mathrm{N}>\mathrm{S}$. O potássio foi o nutriente absorvido em maiores quantidades e o $\mathrm{Mg}$ e o $\mathrm{S}$ em menores quantidades.

Palavras-chave: carqueja, fenóis, nutrição mineral, poda, plantas medicinais. 


\section{MACRONUTRIENTS INTAKE AND TOTAL PHENOL CONTENT ON [BACCHARIS TRIMERA (LESS.) DC.] VAR. CPQBA-1, WITH TWO DIFFERENT PLANTING METHODS, TRIMING AND NOT TRIMING THE UPPER PARTS.}

Dissertação (Mestrado em Agronomia/Horticultura) - Faculdade de Ciências Agronômicas, Universidade Estadual Paulista.

Author: Maurício Augusto Andrião

Adviser: Dr. Luis Vitor Silva do Sacramento

\section{SUMMARY}

The aim of this study was to determine the intake of macronutrients on Baccharis trimera (Less.) DC. var. CPQBA-1 and the phenol content and amount in function of the time. Seedlings were produced from seeds of the Toxic and Medicine Plants Garden of FCF / UNESP in Araraquara. The statistical design was based on the methodology of experimental groups, in this case using two experiments with the same structure, varying only the planting method, trimming the plants at $15 \mathrm{~cm}$ above the ground on one of the experiments. The experimental design on randomized blocks, considered 5 sampling times, every 30 days during 150 days, in four repetitions making a total of 20 plots, composed by two pots and two plants on each pot, totalizing 40 experimental units. The collected materials were dried, ground and analyzed. The evaluations were: dry matter, nutritional status of plants (macronutrients) and total phenol content. Both aerial parts and roots were analyzed. The data collected on both experiments were submitted to group's analysis for the qualitative factor (planting methods) considering the matter production and total phenol contents. The data were submitted to variance analysis and regression analysis for the sampling times with 5\% level of 
probability. The production of dry matter was upward during the 150 crop days, increasing after 90 days after the transplanting (DAT), then decreased in the last 30 days of cultivation. The planting methods did not influence the yield of dry matter on the upper parts and roots, needier the total phenols. The total phenols yield was upward reaching the maximum on the 150 DAT. The order of macronutrients accumulation after 150 days, on the intact plants was $\mathrm{K}>\mathrm{N}>\mathrm{Ca}>\mathrm{P}>\mathrm{Mg}>\mathrm{S}$, and on the trimmed plants was $\mathrm{K}>\mathrm{Ca}>\mathrm{P}>\mathrm{Mg}>\mathrm{N}>\mathrm{S}$. The potassium was the nutrient absorbed in larger quantities and $\mathrm{Mg}$ and $\mathrm{S}$ in smaller quantities.

Key words: carqueja, phenols, mineral nutrition, trimming, medicine plants 


\section{INTRODUÇÃO}

O emprego de vegetais com a finalidade de curar algum tipo de doença que acometam homens e animais, ocorre desde sua própria existência. Ainda hoje, se observa cachorros se alimentando naturalmente com grama devido à contaminação por vermes em seus sistemas digestivos. No passado, as doenças eram vistas como uma punição dos deuses e as curas eram realizadas por curandeiros em rituais que incluíam "poções mágicas" que eram preparadas à base de plantas nativas de cada região ao redor do mundo. Estas plantas foram denominadas como plantas medicinais, que segundo a Organização Mundial da Saúde (WHO, 1998), são espécies vegetais a partir das quais, produtos de interesse terapêutico podem ser obtidos e usados na espécie humana como medicamento.

Descobertas arqueológicas mostram o uso de plantas medicinais há milhares de anos, como é o caso encontrado na região do atual Iraque, mostrando o uso de Achillea millefolium (mil-folhas), por Neandertaus, há 60.000 anos. Existem relatos do uso destes vegetais pelos antigos povos Egípcios, Chineses, Gregos e Indianos em épocas anteriores a de Cristo (FAROOQI \& SREERAMU, 2004). No Brasil, as plantas medicinais 
são utilizadas desde os primórdios das sociedades indígenas, sendo o conhecimento popular repassado de geração a geração.

Apesar do grande desenvolvimento da medicina alopática no século $\mathrm{XX}$, as plantas continuam sendo um dos maiores recursos de medicamentos, tanto na medicina popular quanto moderna. Farooqi \& Sreeramu (2004), citam que aproximadamente um terço de todos os medicamentos utilizados no mundo são originados de plantas e Di Stasi (2007) complementa que apesar da inexistência de dados oficiais, o panorama de consumo no Brasil é considerado similar ao resto do mundo, com agravante de que $66 \%$ da população brasileira não tem acesso aos medicamentos comercializados, fazendo uso das plantas medicinais como única alternativa para o tratamento de suas doenças. Uma vez que o custo da nova tecnologia médica se torna cada vez mais elevado, cria-se obstáculos para a democratização de seus benefícios, além da preocupação com os efeitos colaterais e aparecimento de resistência de patógenos, que atrelados, sugerem que outros modelos terapêuticos devam ser utilizados, o que provoca um tendência definitiva pela procura de produtos à base de vegetais (medicamentos, cosméticos, perfumaria e alimentos).

Neste contexto surgem programas governamentais que visam o desenvolvimento de medicamentos a partir da flora nativa de cada região do planeta. No Brasil, a importância em conhecer este tema, vem se tornando relevante, principalmente com a criação da Política Nacional de Plantas Medicinais e Fitoterápicos, a qual evidenciou uma questão não apenas de opção terapêutica, mas sim de fundamental importância para a saúde da população Brasileira. Grupos interdisciplinares dedicam suas pesquisas interpretando a complexidade etnobotânica, agronômica, farmacêutica e médica da flora nativa, vislumbrando obter novos medicamentos, e plantas produtoras de substâncias farmacologicamente ativas, respeitando valores culturais e ambientais.

Existem no mercado brasileiro dois tipos de plantas medicinais, as exóticas, adquiridas do mercado externo e as nativas, quase na totalidade, obtidas a partir de coletas indiscriminadas, que por sua vez não existem cultivos, ou estão em processo de domesticação, pois conforme citado por Furlan (2005), o estudo na área farmacológica e médica, não foi acompanhado pelo estudo agronômico, sendo este considerado recente no Brasil. 
Dentre as espécies que necessitam de estudos agronômicos encontra-se a carqueja. Esta espécie apresenta origem supostamente brasileira, ocorrendo em quase todo o território nacional, sendo o Paraná considerado o centro de dispersão no país (PAVANFRUEHAUF, 2000). É utilizada na medicina popular por suas atividades antiinflamatórias, analgésicas e antiulcerais (CASTRO \& FERREIRA, 2000) e considerada um dos remédios populares mais utilizados no Brasil (FURLAN, 2005). Trata-se de uma planta medicinal de alto nível de importância, sendo incluída há quase um século, no Código Farmacêutico Brasileiro (PHARMACOPEIA, 1926) e citadas por Vieira \& Silva (2002) como prioritária para desenvolvimento de estratégias de conservação e manejo.

A estimativa de gastos com fitoterápicos no Brasil para o ano 2010 é de US\$ 1 bilhão (HERBARIUM, 2002). Segundo Scheffer et al. (2004), no período de 1990 a 2000 o crescimento na exportação de plantas medicinais foi de $159 \%$ e nas importações, o crescimento foi de $148 \%$. A carqueja é uma das dez espécies medicinais mais comercializadas no Brasil (SILVA JÚNIOR, 1997).

Esta demanda provocou a ampliação do cultivo de ervas evidenciando uma alternativa aos pequenos agricultores. No entanto, os resultados econômicos dependem de inúmeros fatores e risco presentes no cultivo de plantas medicinais, as quais dependem intrinsecamente da interação com o ambiente para a produção de fitomassa em equilíbrio com a produção de fitoquímicos.

No entanto, existem poucas áreas de cultivo desta espécie que sofre diversos problemas como a padronização dos parâmetros da matéria-prima exigidos pela Farmacopéia. O desconhecimento por parte do produtor destes padrões ou mesmo na compreensão das exigências, muitas vezes complexas e impraticáveis no cotidiano, associado a um mercado desfavorável, de preços baixos, flutuantes e, muitas vezes desconhecido, favorecem a presença de intermediários e contribuem para a pressão sobre a biodiversidade e o risco de desaparecimento da espécies.

Estas características geram desestímulo e desistência dos produtores rurais no cultivo de espécies medicinais e mais especificamente de carqueja. Segundo Menezes Jr. (2006) cerca de $90 \%$ das espécies medicinais nativas consumidas no Brasil são provenientes de coletas indiscriminadas. 
O cultivo de plantas medicinais tem adquirido, cada vez mais, espaço nas discussões sobre o meio rural. Tal fato se deve as necessidades de suprir o mercado, seja, junto ao programa do governo federal de implantação da fitoterapia no SUS, o mercado informal de comercialização (incluindo os raizeiros e feirantes) e as grandes indústrias farmacêuticas, todavia existe uma necessidade imediata de subsídio fitotécnico para dar continuidade nesta tendência.

Neste contexto o objetivo deste trabalho foi obter a marcha de absorção de macronutrientes e a produção de fitomassa em partes aéreas e raízes de Baccharis trimera (Less.) DC. var. CPQBA-1, bem como verificar o teor e acúmulo de fenólicos totais em partes aéreas desta mesma variedade, sob dois sistemas de cultivo, com e sem poda no dia do transplantio. 


\section{REVISÃO BIBLIOGRÁFICA}

\subsection{Aspectos botânicos de Baccharis trimera (Less.) DC.}

Baccharis trimera (Less.) DC., popularmente conhecida como carqueja, carqueja-amarga, tiririca de babado, bacanta, cacalia-amarga ou vassoura (LORENZI \& MATOS, 2002), pertence à família Asteraceae, que possui distribuição cosmopolita, com aproximadamente 1600 gêneros e 23000 espécies, sendo no Brasil, representada por 300 gêneros e 2000 espécies (SOUZA \& LORENZI, 2005). Pertencente à subtribo Baccharidinae (De BONA et al. 2002) e ao gênero Baccharis Linnaeus que compreende cerca de 350 espécies, todas americanas. No Brasil, é representado por uma média de 120 espécies, distribuídas em maior concentração na Região Sul (BARROSO, 1976).

Esta espécie apresenta taxonomia difícil (VIEIRA \& SILVA 2002) sendo também citada por suas sinonímias Baccharis genistelloides var. trimera (Less.) Baker (1882) (BARROSO, 1976; CASTRO \& FERREIRA, 2000).

O gênero Baccharis significa "dedicado a Bacchus", deus do vinho, pois na antiguidade os amantes de vinho consideravam uma planta milagrosa, por evitar a 
intoxicação causada pela bebida (ROSA, 1989). O nome trimera, tem relação com os ramos trialados (BARROSO, 1976).

A exsicata da variedade CPQBA-1 está depositada no Herbário do Centro Pluridisciplinar de Pesquisas Químicas Biológicas e Agrícola da UNICAMP, com número 1286.

A carqueja é uma planta dióica, subarbustiva ramificada, com cerca de 1 a 1,6 metros de altura, ereta, racemosa, com folhas muito reduzidas, ramos trialados, com alas interrompidas de forma desigual, estreitas ou largas (cerca de $2 \mathrm{~cm}$ de largura), planas, levemente onduladas, verdes, membranáceas, as vezes brilhantes (SIMÕES et al., 1998; CASTRO, 1996). Possui caule subterrâneo desprovido de alas e raiz ramificada (CASTRO, 1996). As flores unissexuadas estão reunidas em capítulos, agrupados ao longo dos ramos alados, inseridos nas interrupções das alas. O fruto é seco, indeiscente, tipo aquênio (SÁ, 1992 citado por CASTRO \& FERREIRA, 2000). A epiderme dos ramos possui tricomas pluricelulares ramificados que exudam óleos essenciais e compostos tânicos (CASTRO \& FERREIRA, 2000). Testes fitoquímicos realizados nesta espécie demonstraram gotículas de óleos essenciais e compostos tânicos no parênquima das alas, na região cortical do ramo, na epiderme das alas e do ramo, e fazendo parte do depósito extra-cuticular (SÁ, 1992 citado por CASTRO \& FERREIRA, 2000).

\subsection{Aspectos ambientais de B. trimera}

B. trimera apresenta origem supostamente brasileira, ocorrendo em quase todo o território nacional, em altitudes de até 2.800 metros, sendo comum em campos e beiras de estradas, e em diversos tipos de solos (PAVAN-FRUEHAUF, 2000). Barroso (1976) relata ocorrência em Minas Gerais, Rio de Janeiro, São Paulo, Paraná, Santa Catarina, Rio Grande do Sul, Uruguai, Paraguai, Bolívia, e nordeste da Argentina. É considerada uma planta invasora de pastagens, sendo adaptadas a lugares abertos ou campos (CASTRO \& FERREIRA, 2000; De BONA et al. 2002). É uma planta ruderal de Mata Atlântica, que apresenta alta frequiência do gênero Baccharis (VIEIRA \& SILVA, 2002).

Esta planta tem amplo uso popular, sofre forte pressão antrópica e é obtida através de extrativismo. Sua demanda no mercado interno é grande e têm sido bastante explorada ocasionando grande redução de suas populações, desta forma, está citada entre as 
espécies prioritárias para desenvolvimento de estratégias de conservação e manejo, segundo as Estratégias para Conservação e Manejo de Recursos Genéticos de Plantas Medicinais e Aromáticas realizada pela EMBRAPA/IBAMA (VIEIRA \& SILVA 2002).

A produção agrícola é considerada pequena, sendo realizada em poucas propriedades nos estados de São Paulo, Santa Catarina, Rio Grande do Sul e Paraná, o qual é considerado como o estado centro de deposição do país (BARROSO, 1976) e maior produtor nacional (CORRÊA JUNIOR et al., 2006).

\subsection{Aspectos farmacológicos e fitoquímicos de B. trimera}

Baccharis trimera (Less) DC. é uma espécie usada na medicina popular por suas atividades digestiva, diurética, hepatoprotetora, hipoglicêmica, no combate da anemia (CASTRO \& FERRREIRA, 2000; De BONA et al. 2002) e antiemética e antinauseante (BARBANO, 2006). Possui ação terapêutica confirmada para dispepsias (BRANDÃO, 2009) e reumatismo (GENÉ et al., 1996). Trata-se de uma planta medicinal de alto nível de importância, sendo incluída há quase um século, no Código Farmacêutico Brasileiro (Pharmacopéia), possuindo emprego "oficinal" na forma de extrato fluido, tintura e tintura composta (PHARMACOPEIA, 1929). Seu consumo também é feito na forma desidratada íntegra ou rasurada, acondicionada em embalagens plásticas ou na forma de sachês para infusão.

Durante toda a evolução, os seres vivos, incluindo os vegetais, passaram por adaptações ao meio em que vivem num sistema complexo de relação entre os seres bióticos e abióticos. Pela sua natureza, as plantas não conseguem se deslocar para evitar ou se defender de determinados estresses causados pelo ambiente ou por qualquer efeito exógeno, em um determinado momento. Com isso o reino vegetal desenvolveu outras formas de proteção. As formas físicas que são formadas pela cutina e a periderme, que reduzem a perda de água e formam barreiras contra o ataque de patógenos e desenvolveram um grupo de compostos vegetais, conhecido como metabolitos secundários, que segundo Taiz \& Zeiger (2004) defendem os vegetais contra vários herbívoros e microorganismos patogênicos, além de apresentar outras funções importantes como o suporte estrutural e pigmentos. Alguns autores citam outras funções nas plantas, como proteção contra raios UV, a atração de 
polinizadores ou animais dispersores de sementes (SANTOS, 2007), bem como sua participação em alelopatias (HARBONE, 1993).

A todo este conjunto metabólico, embora não necessariamente essenciais para o organismo produtor, garantem vantagens para sua sobrevivência e para a perpetuação da espécie, em seu ecossistema. Uma breve diferenciação entre os metabolismos apresentada por Gottlieb et al. (1996) em que os metabólitos primários são os fornecedores de matéria-prima e de energia para a formação dos metabólitos secundários, designados pelos autores como especiais. Segundo Santos (2007) a origem de todos os metabolismos secundários pode ser resumida a partir do metabolismo da glicose, via dois intermediários principais, o ácido chiquímico e o acetato. Embora classificadas como sendo metabolismo primário e secundário, as reações bioquímicas não ocorrem independentemente em um mesmo organismo, portanto, não existe uma linha nítida divisória entre os dois metabolismos.

O metabolismo secundário freqüentemente apresenta atividades biológicas interessantes. Segundo Santos (2007), muitos são de importância comercial, tanto na área farmacêutica quanto nas áreas alimentícias, agronômicas e perfumarias. Na área farmacêutica o maior interesse deriva principalmente do grande número de substâncias farmacologicamente importantes, sendo a carqueja uma das espécies produtoras destas substâncias.

As carquejas possuem óleos essenciais, contendo monoterpenos (alfapineno, beta-pineno, nopineno), alcoóis sesquisterpênicos (carquejol, ésteres terpênicos) flavonas e flavononas; flavonóides, lactonas e saponina (SANTOS et al., 1988; SIMÕES et al., 1998), além de resina, vitaminas, polifenóis, taninos, alfa e beta cardineno, calameno, eledol e eudesmol (OLIVEIRA e AKISUE, 1997). Soicke e Leng-peschlow (1987) ao estudarem o extrato fresco etanólico de $B$. trimera encontraram uma mistura de cinco flavonóides: quercetina, luteolina, nepetina, apigenina e hispidulina. Pocá (2005) ao realizar a determinação do extrato a aquoso e hidroalcoólico de $B$. trimera a $20 \%$, revelou a presença de flavonóides, taninos, ácidos graxos, esteróides e/ou triterpenóides, cumarinas, aminogrupos e traços glicosídeos saponínicos, os quais foram semelhantes ao encontrado por De Bona (2002). Segundo Brandão (2009) os principais metabólitos secundários produzidos pela carqueja com indicações terapêuticas confirmadas são os polifenóis (proantocianidinas), utilizados no tratamento de dispepsias. 
Dentre as classes de metabólitos secundários presentes nas carqueja, os fenóis apresentam grande importância. Esta classe constitui um grupo quimicamente heterogêneo, com aproximadamente 10000 compostos e devido a sua diversidade química, apresentam, uma variedade de funções (SILVA, 2005). Possuem pelo menos um anel aromático, no qual ao menos um hidrogênio é substituído por um grupamento hidroxila. Neste grupo são encontrados estruturas tão variadas quanto a dos ácidos fenólicos e dos derivados da cumarina, além das ligninas, taninos e estruturas fenólicas encontradas fazendo parte de proteínas, alcalóides e terpenóides (CARVALHO et al. 2007). Os fenóis podem ser classificados, de acordo com o esqueleto básico, em fenóis simples, benzoquinonas; ácidos fenólicos; acetofenonas e ácidos fenilacéticos; fenilpropanóides; ácidos cinâmicos; fenilpropenos; cumarinas; isocumarinas e cromonas; naftoquinonas; xantonas; antraquinonas; flavonóides; lignanas; diflavonóides; melaninas vegetais; ligninas; taninos hidrolisáveis e taninos condensados (CARVALHO et al. 2007).

Nakasugi e Komai (1998) identificaram a ação antimutagênica no extrato metanólico desta espécie. Grance et al. (2008) observaram toxicidade do extrato hidroalcoólico de $B$. trimera em células do fígado e rins de ratas grávidas, todavia este toxicidade se mostra reversiva quando o extrato é empregado de forma descontínua. Oliveira et al. (2005) ressaltam que extratos aquoso, alcoólico e butanólico de carqueja apresentam atividade potencial antidiabética, já Mendes et al. (2007) relataram a ausência de atividade adaptógena nos extratos hidroalcoólicos desta espécie.

As substâncias resinosas e o óleo essencial justificam o uso industrial desta planta na aromatização de refrigerantes e licores, destacando o nopineno, o carquejol e o acetato de carquejila, e dentre eles o ledol em pequena quantidade. Utiliza-se ainda a carqueja na fabricação de cervejas baratas, recomendando-se como substituinte do lúpulo (COSTA, 1994).

\subsection{Aspectos sócio-econômicos de B. trimera}

Adaptações constantes são feitas na agricultura familiar para suprir as tendências de mercado, e é no contexto de um mercado orientado para produção natural de qualidade, que se insere o cultivo de plantas medicinais. A comercialização de plantas 
medicinais pode ser feita de duas formas principais, tanto plantas frescas como plantas desidratadas.

Lourenzani et al. (2004) classifica o mercado de matéria-prima (plantas medicinais) em quatro principais arranjos de canais de distribuição: produtor/extrator comercializa para o intermediário que por sua vez, comercializa para os atacadistas; produtor/extrator comercializa diretamente para atacadistas; produtor/extrator comercializa diretamente para as indústrias de medicamentos fitoterápicos; produtor/extrator comercializa para os varejistas (feiras livres e/ou supermercados).

O mercado mundial de medicamentos fitoterápicos, de acordo com França (2000), movimenta algo em torno de US\$22 bilhões ao ano. Este mercado encontra-se em franca expansão evidenciando crescimento a uma taxa anual acima dos $10 \%$ (MEDICAMENTO, 2001 citado por LOURENZANI et al. 2004).

No Brasil a ampliação deste mercado, deve-se, não somente ao consumo pelas populações tradicionais, mas também pelo programa governamental de inclusão da Fitoterapia no Sistema Único de Saúde e principalmente pela inclusão de grandes empresas farmacêuticas. O mercado de plantas medicinais de 1999 para 2000 aumentou suas vendas em 15\%, e as vendas anuais de fitoterápicos atingiram US\$ 260 milhões em 2002 (VIEIRA \& SILVA, 2002). Os principais medicamentos fitoterápicos em volume de vendas no Brasil movimentam um total de US\$56 milhões por ano, sendo os principais laboratórios fitoterápicos no Brasil de origem européia, seguidos por algumas indústrias brasileiras (SCHULZ et al., 2002). Segundo Lourenzani et al., (2004) o mercado brasileiro de plantas medicinais é ainda desorganizado e amador, respondendo por apenas US\$ 500 milhões do mercado mundial de medicamentos fitoterápicos.

De acordo com Pereira Filho (2001) a produção agrícola de plantas medicinais se expande na agricultura familiar, como pode ser visto no estado do Paraná, onde a área plantada cresceu seis vezes na última década, o que representou, em 1999, mais de 2,2 mil hectares.

Furlan (2005) cita a carqueja como um dos remédios populares mais utilizados no Brasil. Silva Jr. (1997) ressalta que é uma das dez espécies medicinais mais comercializadas no Brasil, já Reis e Mariot (1998) alertam para o fato de que a carqueja é uma das espécies nativas mais exploradas na região do Vale do Ribeira do Iguape (Sudoeste de 
SP). Naiverth \& Faria (2007) destaca que é a quarta planta medicinal mais utilizada na região do município de Pato Branco no estado do Paraná. Pocá (2005) listou alguns produtos encontrados no mercado local de Curitiba, que contém carqueja em sua formulação: Carqueja em cápsulas - Heptaflora do Laboratório Era Nova, além de chás disponíveis em sachês ou em pacotes. Entre as grande indústrias consumidoras de carqueja pode-se destacar a empresa Krys Belt, que compra mensalmente seis toneladas de carqueja seca, que vem do Sul de São Paulo e Minas Gerais, para fabricação do produto de nome fantasia "Coscarque ${ }^{\circledR, " ~(C O ̂ R T E S, ~ 1999) . ~}$

Esta demanda provocou a ampliação do cultivo desta espécie, evidenciando uma alternativa aos pequenos agricultores. No entanto, para a obtenção dos resultados econômicos é necessário superar inúmeros fatores e riscos, os quais dependem intrinsecamente da interação do cultivo com o ambiente.

Embora o mercado brasileiro de plantas medicinais tenha apresentado um elevado crescimento, esse fato não foi acompanhado de uma resposta compatível dos componentes dessa cadeia (BATALHA \& MING, 2003), principalmente em termos de fornecimento de matéria prima, padronização de qualidade da droga vegetal, gestão, tecnologia e mecanismos institucionais.

A complexidade do setor de plantas medicinais perdura desde o cultivo, até processos de transformações das matérias-primas, as quais são dirigidas a setores diferentes e, por conseguinte, fluxos de cadeias produtivas diferentes. Por exemplo os setore de produtos alimentícios, farmacêuticos, cosmético e perfumaria, higiene pessoal e limpeza, cada um com suas peculiaridades, o que dificulta o entendimento da cadeia produtiva, e justifica a ausência de dados na literatura e ausência de metodologias apropriadas para o custeio destas espécies.

Marques et al., (1992) e Marques (1990) evidenciaram que 50\% dos produtos fitoterápicos disponíveis no comércio brasileiro apresentam alguma irregularidade devido à presença de matéria orgânica estranha, sujidades e insetos, problemas de identificação botânica e adulteração. Estes entraves podem ser amenizados através de informações obtidas com pesquisas, tornando-se eminente a necessidade da utilização de técnicas agronômicas que aperfeiçoem o sistema de cultivo, melhorando as condições econômicas para o produtor rural em associação à produção de drogas vegetais de melhor qualidade, diminuindo as coletas indiscriminadas. 


\subsection{Aspectos agronômicos de B. trimera}

Estudos voltados para o desenvolvimento e manejo de plantas com capacidade de sintetizar metabólitos secundários são considerados de suma importância para a preservação da flora medicinal. Apesar da importância ambiental e sócio-econômica, poucos estudos são realizados, principalmente com espécies nativas, como é o caso da carqueja. Segundo Furlan (2005) estudos na área farmacológica e médica, não foram acompanhados pelos estudos agronômicos, sendo estes considerados recentes no Brasil.

Nota-se que a maioria das espécies utilizadas na medicina popular estão próximas ao estado silvestre, e ainda mantém-se em equilíbrio com o meio ambiente. Desta forma, Kamada (1998) ressalta que os estudos de efeitos genéticos e ambientais podem contribuir significativamente nos processos de seleção e aclimatação aos diferentes meios de cultivo. Corrêa Jr. et al. (1994) ressaltam que a elaboração de metabólitos secundários nos vegetais depende basicamente de três fatores: fatores de ordem genética ou endógena, que dependem da carga genética das plantas e são transmitidas de geração em geração, a qual é diferente de espécies para espécie; fatores abióticos, como chuva, vento, solo, latitude e altitude e fatores técnicos como forma de plantio, tratos culturais, épocas de colheita, secagem, transporte e armazenamento. Além dos fatores bióticos que envolvem o ataque de pragas e doenças que podem desencadear mudanças nos teores e composições dos metabólicos secundários.

B. trimera é uma espécie pioneira, tipicamente heliófitas, que permite o uso de estratégias de cultivo tradicional, pois esta se adapta a este tipo de condição (REIS et al., 2007).

Segundo Oliveira e Moresco (1999), Corrêa Jr. et al. (1994 e 2006) e Trani et al. (2007), a época de plantio de B. trimera é de setembro a novembro, com espaçamento de $50 \mathrm{~cm}$ X $30 \mathrm{~cm}$. A propagação pode ser feita por sementes, mudas da planta adulta (CASTRO, 1998), divisão de touceiras (CASTRO, 1998; REIS et al. 2007) e na maioria dos casos por estaquia (BIASE \& De BONA, 2000; De BONA, 2005a;). De Bona et al. (2005b) ressaltam que o processo de estaquia permite a obtenção rápida de plantas uniformes e de sexo conhecido. Sousa, Sacramento e Ming (2006) ao estudarem o enraizamento de estacas de carquejas obtidas em diferentes partes dos ramos das plantas, obtiveram apenas $42 \%$ do 
total de estacas enraizadas, sendo as estacas retiradas das porções basal e mediana, as mais eficientes em termos de enraizamento e sobrevivência. Já Borges Silva et al. (2008) obtiveram melhor enraizamento com estacas de origem apical ou basal.

Segundo Cortés et al. (2007) existem poucas informações dos aspectos nutricionais de plantas nativas e de seu desenvolvimento em ambientes cultivados. Pocá (2005) complementa que são raros na literatura trabalhos sobre nutrição de carqueja e sua relação com o rendimentos de biomassa e síntese de metabólitos secundários. Martins et al. (1995) citam que, dentre os fatores que podem interferir na composição química de uma planta, a nutrição é um dos que merece mais destaque, sendo que, a deficiência ou excesso de nutrientes podem promover maior ou menor produção de princípios ativos. Dechen \& Nachtigall (2007), citam que é necessário que haja disponibilidade e absorção dos nutrientes em proporções adequadas, via solução do solo ou, como suplementação, via foliar, pois cada um destes nutrientes tem função específica no metabolismo das plantas. Assim surge o interesse por conhecer a marcha de absorção de nutrientes, que segundo Malavolta e Fornasieri Filho (1983) pode auxiliar na determinação das épocas em que os elementos são mais exigidos e em que, portanto, a adubação deve ser realizada.

A carqueja é considerada uma espécie rústica, tolera solos muito ácidos e pobres, chegando nestas condições, a atingir altas populações (LORENZI, 2000). Em relação à acidez do solo, levando em consideração a saturação de bases (V\%), indica-se para a correção, o valor de 44,4\% que proporciona maior produção de massa seca (De BONA, 2002). A adubação orgânica proporciona um aumento de fitomassa, com a utilização de 30 a 50 t/ha de esterco de curral ou composto ou 15 a 30 t/ha de esterco de aves ou húmus, sem reduzir o teor de óleo essencial (CORRÊA Jr. et al., 1994; DIAS \& CAMARGO, 1996).

Borella et al. (2001), ao estudarem a influência de adubação mineral (N-P-K) e sazonalidade de colheita no rendimento e teor de flavonóides em indivíduos masculinos de B. trimera não observaram diferenças significativas entre os tratamentos, em relação à produção de fitomassa e produção de flavonóides (rutina), contudo, observaram um aumento na média de peso fresco na colheita realizada na primavera, divergindo da maior média de produção de flavonóides, que ocorreu na colheita realizada no verão.

Pocá (2005) cita que a carqueja cultivada em solos férteis não responde à adubação nitrogenada, principalmente quanto à produção de óleo essencial, 
todavia, Sousa (2005), obteve resultados positivos com relação à adubação organo-mineral, citando que ainda são necessários maiores estudos com relação ao uso de adubos minerais e orgânicos no cultivo desta planta.

Freitas et al. (2004) estudando os teores de fenóis totais em plantas de carqueja, na presença e ausência de adubação mineral, e com inoculação de fungos micorrízicos arbusculares, observaram que a produção de fenóis independe da interação entre adubação e inoculação com os microorganismos, todavia, os fungos micorrízicos arbusculares influenciaram o teor de fenóis totais em carqueja. As maiores produções de fenóis totais foram obtidas em plantas inoculadas com a espécie de fungo Glomus clarum.

Cortés et al. (2007), aplicaram diferentes fontes e doses de nitrogênio para avaliar a produção de fitomassa e óleo essencial em carqueja. Os tratamentos foram 4, 8, $16 \mathrm{~g}$ de nitrogênio por quilo de solo, na forma de uréia e as mesmas doses na forma de esterco ovino aplicados às plantas duas vezes por semestre, levou-se em consideração a eficiência de liberação de nitrogênio pelo esterco de $50 \%$ para o primeiro ano. Estes pesquisadores obtiveram resultados interessantes, pois apesar da carqueja não responder aos tratamentos de doses de nitrogênio quanto à produção de fitomassa e óleo essencial, estas plantas produziram diferentes concentrações e composições dos óleos essenciais. Nas plantas adubadas com esterco ovino, a maior concentração foi de $\beta$-pineno, enquanto o espatulenol apresentou uma leve diminuição na concentração nas plantas que receberam uréia. $O$ carquejol e acetato de carquejila não foram confirmados por estes autores.

Silva et al. (2006) ao realizarem análises quantitativa de dois flavonóides (5,3'-diidróxi-4',6,7-trimetóxiflavona e 5-hidroxi-3',4',6,7-tetrametóxiflavona) em duas populações, silvestre e cultivada, de $B$. trimera coletadas nas estações seca e úmida, observaram que em ambas as populações, os teores de 5,3'-diidróxi-4',6,7-trimetóxiflavona foram maiores, já a flavona 5-hidroxi-3',4',6,7-tetrametóxiflavona, apesar de apresentar menores teores em relação a primeira, suas maiores concentrações foram observadas em plantas silvestres e na estação úmida. Os altos teores de alumínio no solo, podem ter induzido a produção da 5,3'-diidróxi-4',6,7-trimetóxiflavona, funcionando como elicitores abióticos. Apesar das condições de fertilidade dos solos serem bem semelhantes neste estudo e a origem genética das plantas cultivadas não ter sido citada, estes resultados sugerem que o acúmulo de metabólitos pertencentes a uma mesma classe se comporte de forma distinta na mesma 
espécie, sendo necessários estudos específicos para diferentes compostos dentro da mesma classe. Silva et al. (2007), em experimento semelhante, porém analisando os teores de fenóis totais expressos em tanino e em diferentes horários do dia $(6,12$ e 18h), observaram que em ambas as populações os teores de fenóis não diferiram significativamente entre si, independentemente do período de colheita, entretanto, os teores foram maiores para ambas as populações nas épocas do ano com menores precipitações e menor umidade no solo. Estas épocas do ano, também coincidiram com o período de menor desenvolvimento vegetativo das plantas. De acordo com Herms \& Mattson (1992), existe uma tendência nos compostos químicos ricos em carbono, como os fenóis, em ter correlação negativa com crescimento e vigor das plantas. As diferenças entre os compostos químicos e conseqüentemente os teores de fenóis produzidos por uma planta, podem ser causados, segundo Brown Junior (1988), pela variabilidade genética e fatores fisiológicos.

A colheita de carqueja é realizada manualmente com a utilização de tesoura de poda. De Bona (2002) recomenda a colheita após o quinto mês, no início da floração, no entanto Martins et al. (1995) sugerem que estas sejam realizadas no quarto mês após o plantio e Furlan (2005) indica o início da colheita com seis meses após plantio. Observa-se na prática que o produtor ainda não tem subsídios para definir a altura de poda, sendo que Mol et al. (2002) e De Bona (2002) sugerem a altura ideal para poda deixando-se 10 cm do caule para rebrota. Castro (2001) enfatiza que a colheita não pode ser realizada muito baixa ou na altura do colo da planta, pois esta proporciona um índice muito alto de mortalidade.

Após a colheita, realiza-se o beneficiamento, o qual engloba a secagem e picagem das ervas. Esta etapa da produção de carqueja merece bastante atenção, pois Corrêa Jr. et al. (1994) e Reis (2007) afirmam que deve ser feita rapidamente com o intuito de interromper as atividades enzimáticas e, por conseguinte, diminuir a degradação dos princípios ativos.

Quanto a produtividade, o rendimento médio de carqueja por hectare é de 1,5 a 2,5 toneladas de matéria seca por colheita, sendo recomendado de duas a três colheitas por ano (CORRÊA Jr. et al., 2006; ANDRIÃO et al. 2008). 


\section{MATERIAL E MÉTODOS}

\subsection{Caracterização da espécie e variedade}

A carqueja, Baccharis trimera (Less.) DC, pertence à Angiospermae, família Asteraceae, gênero Baccharis, seção Caulopterae e tribo Baccharidinae (BARROSO, 1976 e HEIDEN, 2005). Apresenta uma grande variedade de nomes vulgares: carqueja, carqueja-amarga, bacanta, bacorida, cacalia-amarga, carque, quina-de-condomine, vassoura, vassoura de botão e tiririca-de-babado (ALZUGARAY \& ALZUGARAY, 1988) e carquejadoce (PAVAN-FRUEHAUF, 2000). A variedade estudada é denominada "CPQBA-1", registrada no Ministério da Agricultura, Pecuária e Abastecimento pelo Centro Pluridisciplinar de Pesquisas Químicas, Biológicas e Agrícolas da Universidade Estadual de Campinas. Esta variedade foi selecionada pelo processo massal com controle gamético por cinco gerações, incluindo a geração parental. A exsicata "typus” está depositada no Herbário CPQBA sob número 1286. 


\subsection{Obtenção do material botânico e formação das mudas}

Sementes foram coletadas das matrizes da coleção de variedades de plantas medicinais do Centro Pluridisciplinar de Pesquisas Químicas, Biológicas e Agrícolas CPQBA/UNICAMP. As mudas foram produzidas no viveiro de mudas do CPQBA/UNICAMP em tubetes dispostos em bancadas, conforme recomendado por Biasi \& Bona (2000) durante os meses de novembro, dezembro de 2008 e janeiro de 2009. O substrato para o enraizamento constou de uma mistura de areia e vermiculita na proporção de 2:1. A irrigação foi feita por micro-aspersão, programada quatro vezes ao dia, 06:00, 10:00, 14:00 e 18:00h, durante 10 minutos, sendo a temperatura mantida na faixa de 27 à $35^{\circ} \mathrm{C}$ e umidade relativa do ar a $50-60 \%$.

\subsection{Caracterização da área experimental}

O experimento foi conduzido entre fevereiro e junho de 2009 em casa de vegetação do Horto de Plantas Medicinais e Tóxicas do Departamento de Princípios Ativos Naturais e Toxicologia da Faculdade de Ciências Farmacêuticas da Universidade Estadual Paulista, Campus de Araraquara (FCF/UNESP), cujas coordenadas geográficas são $21^{\circ} 48^{\prime}$ $51,4^{\prime \prime}$ de latitude Sul e $48^{\circ} 12^{\prime}$ '5,1" de longitude Oeste, numa altitude de 661 metros.

\subsection{Delineamento estatístico}

Adotou-se a metodologia de grupos de experimentos, sendo para o presente caso, dois experimentos idênticos em estrutura e distintos no manejo no transplantio.. Os dois manejos constaram de uma poda a $15 \mathrm{~cm}$ contados a partir do nível do solo e sem poda na ocasião do transplantio.

O delineamento experimental para cada um dos experimentos constou de ensaio em blocos casualizados (DBC), considerando-se cinco épocas de amostragem num intervalo de 30 dias durante 150 dias e quatro repetições, perfazendo-se um total de 20 parcelas, cada qual composta por dois vasos com duas plantas em cada vaso.

\subsection{Instalação e condução do experimento}

As mudas obtidas foram transplantadas para vasos com volume de $5 \mathrm{~L}$, após três meses de formação, quando atingiram $30 \mathrm{~cm}$ de altura. Foram utilizadas duas mudas 
por vaso, espaçadas em $10 \mathrm{~cm}$, e cada vaso foi espaçado $30 \mathrm{~cm}$ entre si, dispostos em bancadas de aço galvanizado de $10 \mathrm{~m}$ de comprimento por 1,20 m de largura, conforme mostrado na Figura 1.

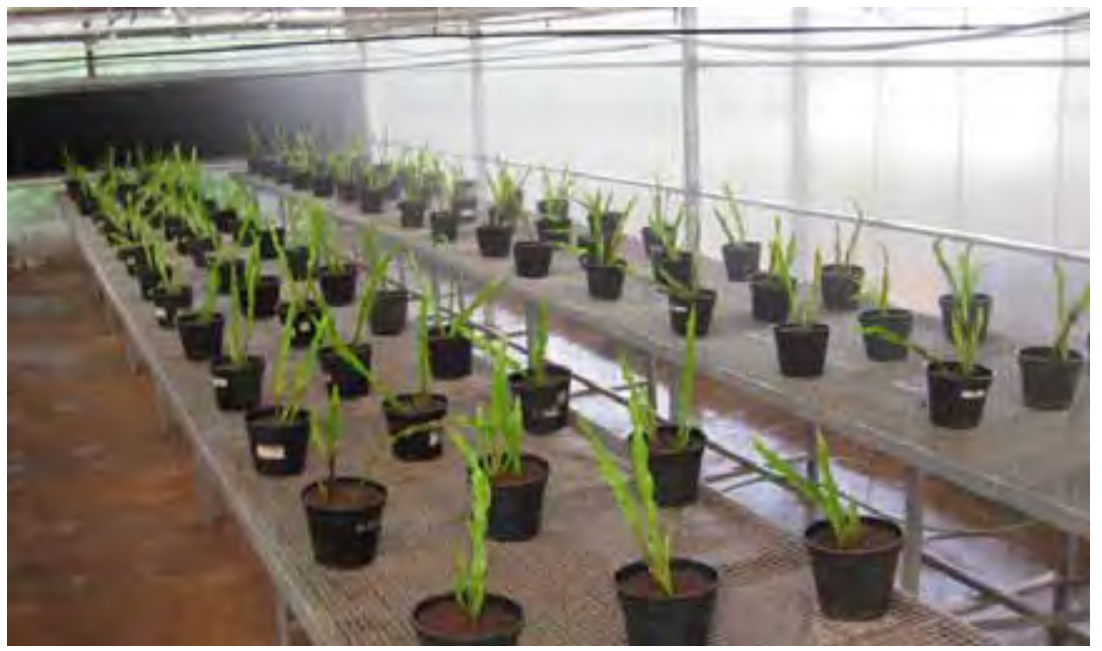

Figura 1. Disposição dos vasos de plantas de carqueja var. CPQBA-1 cultivadas em casa de vegetação do Horto de Plantas Medicinais e Tóxicas do Departamento de Princípios Ativos Naturais e Toxicologia da FCF/UNESP. Araraquara, SP, 2009.

O solo, classificado como Latossolo Vermelho-Amarelo (EMBRAPA, 1999), utilizado para o preenchimento dos vasos foi obtido no Horto da FCF/UNESP. Foram retiradas amostras compostas, as quais foram homogeneizadas e submetidas à análise no Laboratório de Análises de Solos do Instituto de Química da Universidade Estadual Paulista, Campus de Araraquara (IQ/UNESP), para avaliação de suas características químicas de interesse para a fertilidade, conforme mostrado na Tabela 1. Não se fez necessário a correção da acidez do solo.

Tabela 1. Análise das características do solo do Horto de Plantas Medicinais e Tóxicas do Departamento de Princípios Ativos Naturais e Toxicologia da FCF/UNESP, antes da implantação do experimento. Araraquara, SP, 2008.

\begin{tabular}{|c|c|c|c|c|c|c|c|c|c|}
\hline $\begin{array}{c}\mathrm{pH} \\
\mathrm{CaCl}_{2}\end{array}$ & $\begin{array}{l}\text { M.O. } \\
\mathrm{g} \mathrm{dm}^{-3}\end{array}$ & $\begin{array}{l}P_{\text {resina }} \\
\mathrm{mg} \mathrm{dm}^{-3}\end{array}$ & $\mathrm{H}+\mathrm{Al}$ & $\mathrm{K}$ & $\mathrm{Ca}$ & $\begin{array}{l}\mathrm{Mg} \\
\mathrm{cdm}^{-3}\end{array}$ & SB & CTC & V\% \\
\hline 5,6 & 36 & 26 & 24 & 0,6 & 76 & 6 & 83 & 107 & 78 \\
\hline
\end{tabular}


Com o objetivo de manter as boas condições físico-químicas do solo e ofertar condições favoráveis para o desenvolvimento das plantas em vaso, foram realizadas adubações de plantio e cobertura, baseados nos melhores resultados de produção de carqueja obtidos por Sousa (2005). A adubação de plantio foi feita com esterco bovino curtido e peneirado, seguindo recomendações de Raij et al. (1997) para a maioria das espécies de plantas medicinais, na dose de 30 toneladas por hectare, equivalente a 75 g por vaso. Para evitar a contaminação com plantas daninhas utilizou-se esterco proveniente de granja leiteira, o qual foi submetido a análise no Laboratório de Solos do Departamento de Recursos Naturais, área de Ciência do Solo da Faculdade de Ciências Agronômicas da UNESP de Botucatu, conforme mostrado na Tabela 2.

Tabela 2. Análise das características do esterco bovino. Botucatu, SP, 2009.

\begin{tabular}{ccccccccc}
\hline $\mathrm{N}$ & $\mathrm{P}_{2} \mathrm{O}_{5}$ & $\mathrm{~K}_{2} \mathrm{O}$ & $\mathrm{Ca}$ & $\mathrm{Mg}$ & $\mathrm{S}$ & $\mathrm{UM}$. & M.O. & $\mathrm{C}$ \\
\hline 1,70 & 1,12 & 0,16 & 1,50 & 0,87 & 0,37 & 30,00 & 38,00 & 21,10 \\
\hline
\end{tabular}

M.O. = matéria orgânica; UM. = umidade.

O solo foi misturado com o esterco em bandejas plásticas e posteriormente colocado nos vasos. No decorrer do experimento, foram realizadas duas adubações químicas de cobertura, que devido a ausência de informações nutricionais precisas para a cultura da carqueja, foram baseadas em recomendações de Raij et al. (1997) para outras espécies medicinais. A primeira cobertura foi realizada no $35^{\circ}$ dia após o transplantio, nas proporções de $30 \mathrm{~kg}$ de $\mathrm{N} \mathrm{ha}^{-1}, 13 \mathrm{~kg}_{\text {de }} \mathrm{P}^{-1}$ e $30 \mathrm{~kg}^{-1 e} \mathrm{~K} \mathrm{ha}^{-1}$, aplicada na forma sólida sobre o solo, seguido de irrigação. A segunda cobertura foi realizada no $55^{\circ}$ dia após o

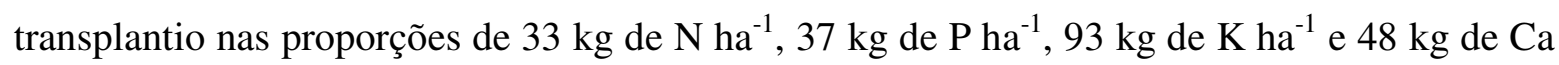
$\mathrm{ha}^{-1}$ sendo aplicada na forma líquida em cada vaso. Os fertilizantes e as quantidades aplicadas em cada vaso foram os seguintes:

$\left.\mathbf{1}^{\mathbf{a}}\right)$ Fosfato de Sódio - $\mathrm{NaH}_{2} \mathrm{PO}_{4} \cdot \mathrm{H}_{2} \mathrm{O}\left(0,15 \mathrm{~g}_{\text {vaso }}{ }^{-1}\right)$; Sulfato de Amônio - $\left(\mathrm{NH}_{4}\right)_{2} \mathrm{SO}_{4}$ $\left(0,35 \mathrm{~g}_{\text {vaso }}{ }^{-1}\right)$; Cloreto de Potássio $-\mathrm{KCl}\left(0,12 \mathrm{~g}\right.$ vaso $\left.^{-1}\right)$.

$\mathbf{2}^{\mathbf{a}}$ ) Fosfato de Potássio di-básico $-\mathrm{K}_{2} \mathrm{HPO}_{4}\left(0,522 \mathrm{~g}\right.$ vaso $\left.{ }^{-1}\right)$; Nitrato de Cálcio $\mathrm{Ca}\left(\mathrm{NO}_{3}\right) \cdot 4 \mathrm{H}_{2} \mathrm{O}\left(0,708\right.$ g $\left.^{\text {vaso }^{-1}}\right)$. 
A irrigação dos vasos foi feita por micro-aspersão, programada quatro vezes ao dia $-06: 00 \mathrm{~h}, 10: 00 \mathrm{~h}, 14: 00 \mathrm{~h}$ e 18:00h, durante 20 minutos. A temperatura foi mantida na faixa de 27 a $35^{\circ} \mathrm{C}$ e umidade relativa do ar a 50-60\%.

Para realização do tratamento de manejo, no dia da implantação do experimento realizou-se a poda das plantas utilizando-se tesouras de poda, na altura de $15 \mathrm{~cm}$ a partir do solo em 40 vasos dispostos na bancadas, conforme mostrado na Figura 2.

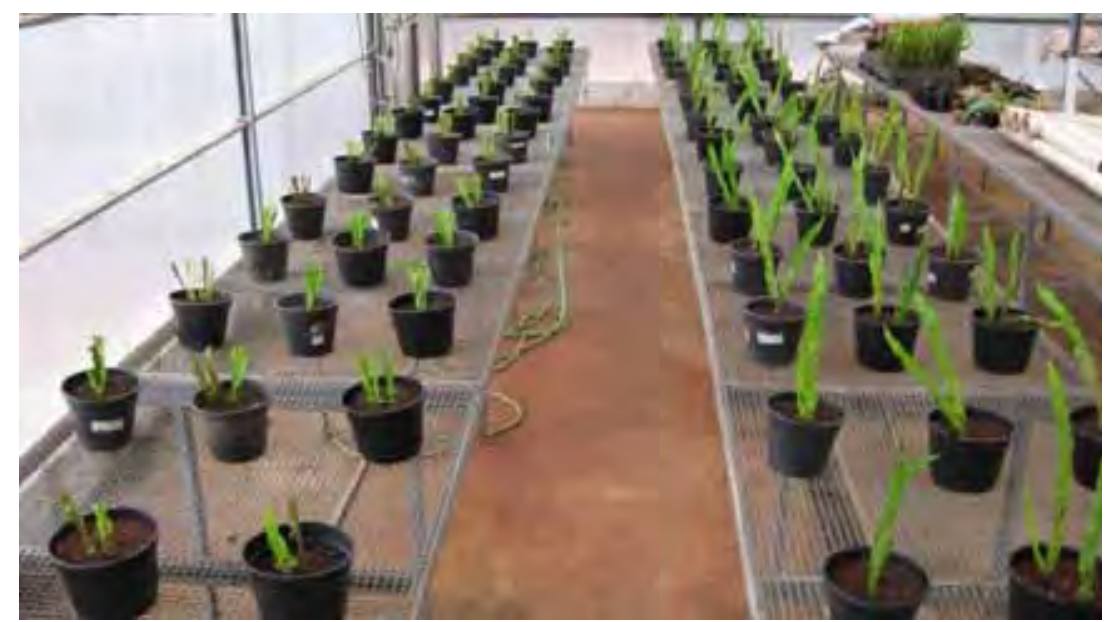

Figura 2. Tratamento de manejo: mudas de carqueja var. CPQBA-1 com poda a partir de 15 $\mathrm{cm}$ do solo no dia do transplantio e sem poda no dia do transplantio. Araraquara, SP, 2009.

As amostragens foram realizadas sempre no período da manhã, de 30 em 30 dias durante 150 dias, com início em fevereiro e término em julho de 2009. Cada amostragem, caracterizada como coleta destrutiva, foi representada por dois vasos de cada bloco, totalizando 16 vasos por amostragem (oito com poda e oito sem poda). A primeira foi realizada 30 dias após transplantio e representou o tempo zero, pois levou-se em consideração o tempo de adaptação das mudas às mudanças edafoclimáticas entre as estufas de enraizamento e de condução do experimento. Nas ocasiões das amostragens a partes aéreas foram separadas das raízes. As raízes foram limpas manualmente em baldes contendo água, para a máxima retirada das partículas do solo que estavam aderentes à superfície radicular, com intuito de evitar superestimação da fitomassa, bem como a contaminação natural com o solo nas análises nutricionais. As partes foram acondicionadas separadamente em sacos de 
papel e deixadas em estufa com circulação forçada de ar a $40^{\circ} \mathrm{C}$, até a estabilização da massa para posterior determinação da fitomassa seca, conforme Falkenberg et al. (2007).

Durante o período em que foi desenvolvido o experimento, ocorreram algumas pragas e doenças. No segundo mês de cultivo, constatou-se a presença de oídio da espécie Oidium baccharidis, o qual foi controlado com fungicida Tiametoxam do grupo químico sistêmico neonicotinóides. Nos meses subseqüentes ocorreram ataques de pulgões verdes e ácaros brancos, os quais foram controlados com extrato de timbó (rotenona) e abamectina, respectivamente.

\subsection{Variáveis analisadas}

\subsubsection{Matéria seca}

Após a estabilização da massa do material vegetal secado em estufa com circulação de ar foi determinada a massa da matéria seca em balança semi-analítica com três casas decimais, sendo definida como o somatório das duas plantas por parcela, expressa em gramas.

\subsubsection{Acúmulo de macronutrientes}

Foram coletadas amostras da matéria seca das raízes e partes aéreas, as quais foram trituradas em moinho tipo Willey. Os extratos sulfúricos e nítrico-perclóricos empregados nas análises dos macronutrientes foram elaborados seguindo-se as recomendações de Malavolta et al. (1997) no Laboratório de Botânica do Departamento de Princípios Ativos Naturais e Toxicologia da FCF/UNESP. Os teores de nitrogênio, também foram analisados neste laboratório, enquanto os teores de $\mathrm{P}, \mathrm{K}, \mathrm{Ca}, \mathrm{Mg}$ e $\mathrm{S}$ foram determinados no Laboratório de Análises de Solos do Departamento de Recursos Naturais, área de Ciência do Solo da FCA/UNESP de Botucatu, seguindo recomendações de Malavolta et al. (1997). Os acúmulos foram calculados baseados na fitomassa das partes aéreas e raízes.

\subsubsection{Determinação do teor e acúmulo de fenólicos totais}

A determinação do teor e acúmulo de fenólicos totais foi realizada em amostras referentes a cinco épocas de amostragem (30, 60, 90, 120 e 150 dias após o transplantio), seguindo mesma metodologia de coleta e secagem das partes aéreas citada no 
item 5.5. A determinação do teor de fenólicos totais foi realizada no Laboratório de Botânica do Departamento de Princípios Ativos Naturais e Toxicologia da FCF/UNESP. Os acúmulos foram calculados baseados na fitomassa das partes aéreas e raízes.

\subsubsection{Obtenção dos extratos}

Para obtenção dos extratos utilizou-se $0,2 \mathrm{~g}$ de cada amostra de carqueja seca e moída. Esta quantidade de material foi acondicionada em tubos de ensaio, acrescentando-se $10 \mathrm{ml}$ de metanol grau HPLC. Com intuito de agilizar o processo de extração, submeteu-se as misturas em banho de ultra-som (freqüência $37 \mathrm{KHz}$ ) por 30 minutos numa temperatura de $30^{\circ} \mathrm{C}$. Em seguida, as misturas foram filtradas em papel filtro com poros de $28 \mu \mathrm{m}$. Os extratos obtidos foram armazenados em frascos de vidro âmbar em refrigerador até $10^{\circ} \mathrm{C}$.

\subsubsection{Curva padrão e doseamento dos fenólicos totais}

Para a construção da curva padrão $\left(0,2,4,6,8\right.$ e $\left.10, \mathrm{mg} \mathrm{L}^{-1}\right)$ utilizouse o ácido gálico, substância padrão recomendada por SINGLETON et al. (1999), BORA et al. (2005) e SARIKAYA et al. (2009), conforme pode ser visualizado na Figura 3.

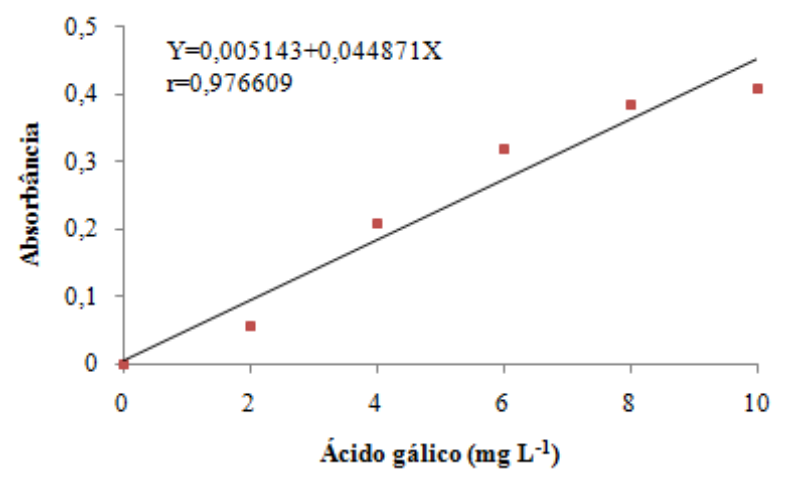

Figura 3. Curva de regressão para soluções de ácido gálico empregadas como padrão de referência na determinação de compostos fenólicos totais.

Para o doseamento dos fenólicos totais bem como a determinação da curva-padrão de ácido gálico utilizou-se o reagente Folin-Ciocalteau segundo a metodologia descrita por SINGLETON et al. (1999), modificada quanto às concentrações dos reagentes: Folin-Ciocalteu 1:10 e $\mathrm{Na}_{2} \mathrm{CO}_{3}$ 7,5\%. Estas modificações adotadas foram resultantes de 
ensaios preliminares com a finalidade de validar a metodologia para os extratos de $B$. trimera do experimento.

Tomaram-se alíquotas de $0,25 \mathrm{ml}$ de cada extrato, transferindo-as para balões volumétricos de $25 \mathrm{ml}$, acrescentando-se $15 \mathrm{ml}$ de água destilada. Em seguida, foram acrescentados 1,25 $\mathrm{ml}$ do reagente Folin-Ciocalteu, e após um tempo máximo de $8 \mathrm{~min}$, foram adicionados $3,75 \mathrm{ml}$ de $\mathrm{Na}_{2} \mathrm{CO}_{3} 7,5 \%$, completando-se o volume dos balões com água destilada. Após duas horas, pode-se observar todo o desenvolvimento da cor azul escuro nos balões, procedendo-se em seguida a leitura da absorbância em $760 \mathrm{~nm}$ em espectrofotômetro $\left(\right.$ FEMTO $\left.^{\circledR}\right)$. As análises foram feitas em triplicatas.

O teor de fenólicos totais de cada amostra foi estimado com base no ácido gálico, multiplicando-se os teores obtidos na equação gerada pela curva padrão por um fator de 0,2 , o qual foi determinado embutindo-se o fator de diluição e as transformações das unidades referências.

\subsection{Análise estatística}

As análises estatísticas foram realizadas empregando-se o software SANEST- Sistema de Análise Estatística para Microcomputadores.

Realizou-se uma análise conjunta dos dois experimentos objetivando reconhecer a hipótese de diferenças existentes entre os níveis do fator qualitativo (manejo), considerando-se as variáveis produção de matéria seca da parte aérea e raízes e acúmulo de fenólicos totais.

Todos os valores obtidos para as variáveis observadas foram submetidos à análise de variância e análise de regressão para as épocas de amostragem observando-se as recomendações de Banzatto \& Kronka (1992) e Pimentel-Gomes \& Garcia (2002) e considerando o nível de 5\% de probabilidade.

Executou-se também um estudo da homocedasticidade entre as variâncias de acordo com NOGUEIRA (1991) visando uma transformação de dados, bem como a determinação de seus parâmetros, realizando-se os cálculos com o auxílio do aplicativo Microsoft Excel. 


\section{RESULTADOS E DISCUSSÃO}

Os resultados obtidos neste trabalho permitiram a interpretação das respostas da espécie $B$. trimera variedade CPQBA-1 frente à absorção dos macronutrientes presentes no solo e fertilizantes, além de propiciar, a compreensão da produção de matéria seca nas diferentes partes das plantas e dos compostos fenólicos totais nas partes aéreas em relação ao tempo de cultivo.

Para a interpretação dos dados obtidos neste experimento, levou-se em consideração não somente os fatores intrínsecos a esta variedade, mas também às variáveis contidas em um sistema de cultivo protegido e, principalmente, no cultivo em vasos.

Os resultados demonstraram características intrínsecas à variedade, sendo distinguidos dos resultados obtidos em outras pesquisas desenvolvidas com a mesma espécie, no entanto, utilizando-se outros acessos. Notou-se grande variação na produtividade de matéria seca entre as repetições do mesmo tratamento, além de variações nas alturas e arquiteturas das plantas. O experimento foi implantado com sementes de uma espécie dióica e apesar das matrizes terem sido de variedades selecionadas pelo processo massal com controle gamético por cinco gerações, observou-se que existe uma alta variabilidade genética nesta variedade. 
Outras constatações que corroboraram para esta hipótese, foram os ataques de pragas e doenças, constatando-se a presença de ácaro branco, pulgões e oídio. Não obstante, constatou-se a presença deste ataque, não apenas nas plantas utilizadas para este experimento realizado em casa de vegetação, mas em outras plantas da mesma variedade cultivadas fora da casa de vegetação e na área do Horto de Plantas Medicinais da FCFUNESP, em Araraquara. Esta constatação conduziu a interpretação de que esta variedade possa ser susceptível ao ataque de algumas pragas e doenças, apesar de apresentar características de alta produtividade de matéria seca, assim como, vigor e coloração exuberante. Esta hipótese encontra reforço na constatação feita por Sacramento \& Appezzatoda-Gloria (2009), que ao realizarem o estudo anatômico de exsicatas de carqueja, observaram que a amostra do "typus" referente às plantas empregadas neste experimento não apresentava formação de cera epicuticular e depósito de compostos fenólicos decorrentes do ataque de fungos encontrados em outras amostras, sugerindo uma susceptibilidade ambiental para as plantas desta variedade.

\subsection{Matéria seca}

As plantas de carqueja apresentaram acúmulo de matéria seca linear ascendente durante os 150 dias de cultivo, tanto para raízes como para partes aéreas, conforme mostrado na Figura 4. Este experimento demonstrou que as plantas cultivadas durante cinco meses acumularam nas partes aéreas, 13,40 e 10,65 $\mathrm{g}_{\text {planta }}{ }^{-1}$ com e sem poda no dia do transplantio, respectivamente, conforme mostrado na Tabela 3. Estas produções foram similares às produções de $B$. trimera obtidas por Freitas et al. (2004), que obtiveram 7,36 g planta $^{-1}$ sem adubação e 17,13 g planta $^{-1}$ com adubação, durante 168 dias de cultivo em casa de vegetação. No entanto Borella et al. (2001) ao realizarem colheitas após 6, 9 e 12 meses do plantio em campo, variando em 8 diferentes adubações, obtiveram médias muito superiores, variando entre 133 e $243 \mathrm{~g}$ planta $^{-1}$, provavelmente, pela característica da população utilizada e pela alta fertilidade inicial do solo. Destarte, ao extrapolar estes valores para o cultivo de um hectare no espaçamento de $0,3 \times 0,5 \mathrm{~m}$, obter-se-ia em média a produtividade de matéria seca de 893 e $710 \mathrm{~kg} \mathrm{hectare}^{-1}$ colheita $^{-1}$, com e sem poda respectivamente, valores inferiores aos $2000 \mathrm{~kg}$ de matéria seca por colheita, relatados por Andrião et al. (2010). 

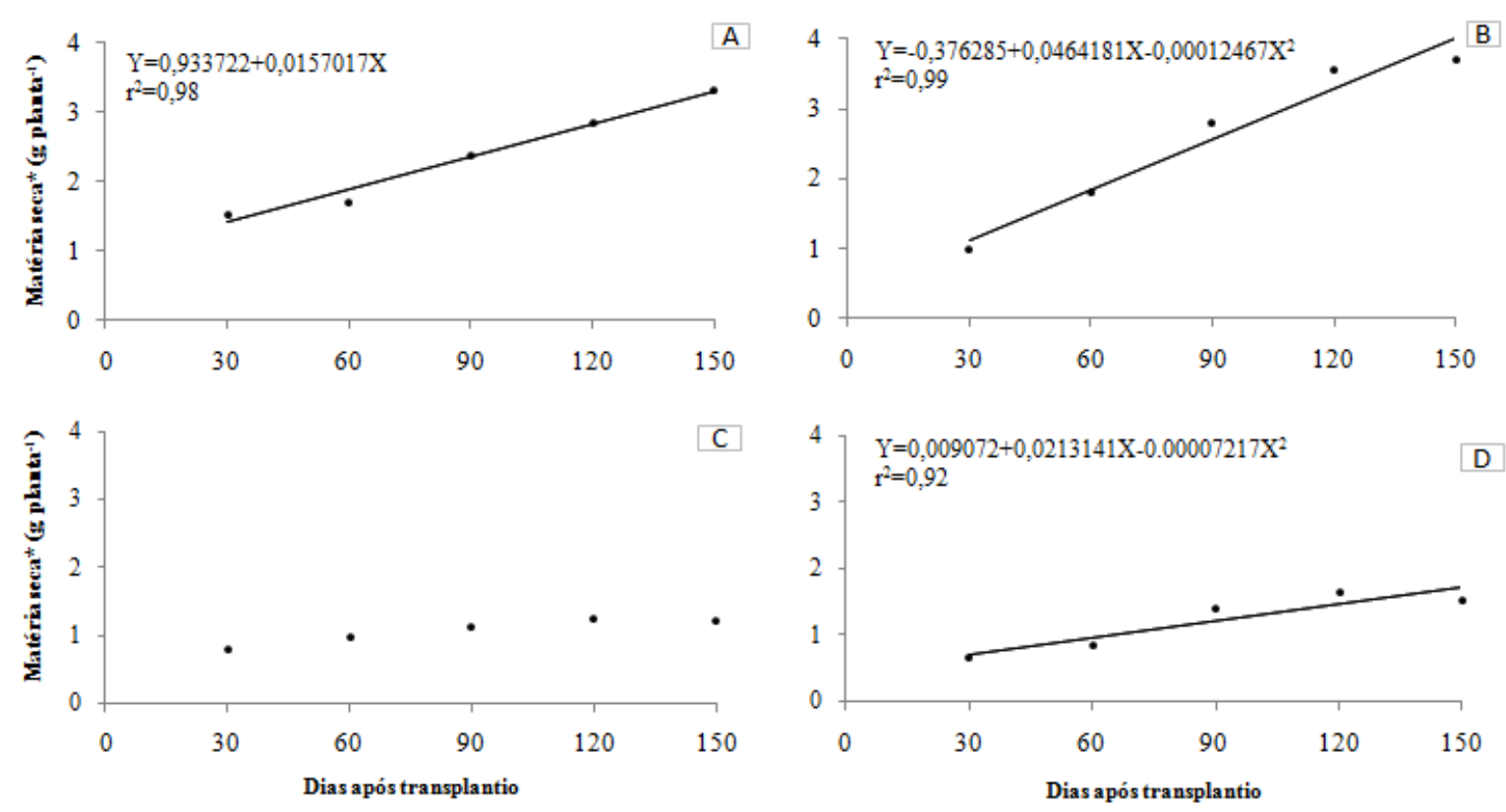

Figura 4. Produção de matéria seca de plantas de carqueja var. CPQBA-1 cultivadas em vasos em casa de vegetação durante 150 dias. (A): Parte aérea - sem poda no transplantio; (B): Parte aérea - com poda no transplantio; (C) Raiz - sem poda no transplantio; (D) Raiz - com poda no transplantio. FCF/UNESP. Araraquara, $\mathrm{SP}, 2009$. *médias transformadas $\left(\sqrt{\mathrm{x}}_{\mathrm{x}+\mathrm{y}}\right)$.

Em relação às diferenças observadas entre os sistemas de cultivo, tanto o sistema radicular, quanto as partes aéreas mostraram-se responsivas à poda no dia do transplantio, demonstrando médias superiores às médias obtidas nas plantas que não receberam a poda no transplantio. Nota-se pela Tabela 3, que as partes aéreas das plantas que receberam a poda produziram menos matéria seca do que as que permaneceram intactas até os 30 dias após transplantio (DAT). No entanto, a partir desta data, passaram a produzir mais do que as intactas, fato justificado pela emissão de novas brotações e o rápido crescimento relatado na Figura 4B. 
Tabela 3. Produção média de matéria seca da parte aérea e raízes de carqueja cultivada sob dois sistemas de cultivo, com e sem poda no dia de transplantio. Araraquara, SP, 2009.

\begin{tabular}{lcccc}
\hline \multirow{2}{*}{$\begin{array}{c}\text { Dias } \\
\text { transplantio }\end{array}$} & \multicolumn{2}{c}{ Parte Aérea } & \multicolumn{2}{c}{ Raiz } \\
& Com Poda & $\begin{array}{c}\text { Sem Poda } \\
\text { Com Poda }\end{array}$ & Sem Poda \\
\hline 30 & 0,66 & 2,04 & 0,14 & 0,32 \\
60 & 2,96 & 2,54 & 0,41 & 0,63 \\
90 & 7,46 & 5,30 & 1,67 & 0,95 \\
120 & 12,37 & 7,76 & 2,35 & 1,24 \\
150 & 13,40 & 10,65 & 2,01 & 1,15 \\
\hline C.V. $(\%)$ & 10,54 & 10,68 & 11,48 & 24,98 \\
\hline
\end{tabular}

\subsection{Marcha de absorção de macronutrientes}

Os resultados apresentados nas Tabelas 4 a 7 e nas Figuras 5 a 11 representam os teores e os acúmulos, respectivamente, dos macronutrientes presentes nas partes aéreas e raízes de carqueja, sem e com poda no transplantio, ao longo do tempo. As quantidades absorvidas de macronutrientes permitiram avaliar com maior precisão as respostas que as plantas de carqueja, variedade CPQBA-1, tiveram às condições de solo e climas oferecidas neste experimento.

A ordem de acúmulo dos macronutrientes após 150 dias de cultivo, presente na parte aérea e sistema radicular das plantas, mostraram-se diferentes entre os tratamentos de manejo no transplantio. Plantas que não receberam poda no transplantio: $\mathrm{K}>\mathrm{N}$ $>\mathrm{Ca}>\mathrm{P}>\mathrm{Mg}>\mathrm{S}$. E plantas que receberam a poda no transplantio: $\mathrm{K}>\mathrm{Ca}>\mathrm{P}>\mathrm{Mg}>\mathrm{N}>$ S. Estas ordens de acúmulo mostraram-se diferentes da ordem de extração obtida por Cortés et al. (2007) ao quantificarem os nutrientes nas partes aéreas de carqueja após seis meses de cultivo sob influencia de diferentes adubações nitrogenadas, obtendo-se a seguinte ordem: $\mathrm{K}>$ $\mathrm{N}>\mathrm{Ca}>\mathrm{Mg}>\mathrm{S}>\mathrm{P}$.

Com intuito de realizar uma discussão global das respostas apresentadas por esta variedade de carqueja, optou-se pela discussão específica de cada macronutriente quanto aos acúmulos, o que permitiu a compreensão das tendências e das possíveis variáveis que influenciaram a produção de matéria seca e compostos fenólicos totais. 
Tabela 4. Teores de macronutrientes em partes aéreas de plantas de carqueja var. CPQBA-1 cultivadas em vasos em casa de vegetação durante 150 dias, sem poda no dia de transplantio. Araraquara, SP, 2009.

\begin{tabular}{|c|c|c|c|c|c|c|}
\hline \multirow{3}{*}{$\begin{array}{l}\text { Dias após } \\
\text { transplantio }\end{array}$} & \multicolumn{6}{|c|}{ Macronutrientes } \\
\hline & $\mathrm{N}$ & $\mathrm{P}$ & $\mathrm{K}$ & $\mathrm{Ca}$ & $\mathrm{Mg}$ & $\mathrm{S}$ \\
\hline & & & -..-g kg & & & \\
\hline 30 & 6,21 & 1,45 & 17,25 & 5,75 & 1,93 & 1,50 \\
\hline 60 & 9,29 & 3,18 & 27,50 & 8,00 & 2,43 & 1,90 \\
\hline 90 & 11,58 & 4,77 & 38,68 & 10,00 & 3,70 & 2,30 \\
\hline 120 & 8,07 & 3,55 & 29,50 & 7,50 & 3,05 & 1,95 \\
\hline 150 & 7,03 & 3,53 & 28,75 & 7,00 & 2,43 & 2,13 \\
\hline
\end{tabular}

Tabela 5. Teores de macronutrientes em raízes de plantas de carqueja var. CPQBA-1 cultivadas em vasos em casa de vegetação durante 150 dias, sem poda no dia de transplantio. Araraquara, SP, 2009.

\begin{tabular}{|c|c|c|c|c|c|c|}
\hline \multirow{3}{*}{$\begin{array}{l}\text { Dias após } \\
\text { transplantio }\end{array}$} & \multicolumn{6}{|c|}{ Macronutrientes } \\
\hline & $\mathrm{N}$ & $\mathrm{P}$ & $\mathrm{K}$ & $\mathrm{Ca}$ & $\mathrm{Mg}$ & $\mathrm{S}$ \\
\hline & \multicolumn{6}{|c|}{ 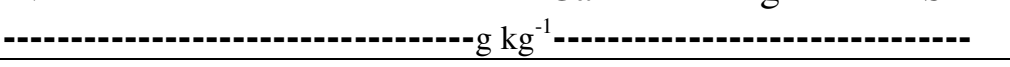 } \\
\hline 30 & 5,82 & 2,82 & 24,50 & 5,00 & 3,55 & 3,20 \\
\hline 60 & 8,64 & 7,08 & 41,75 & 6,75 & 2,98 & 4,78 \\
\hline 90 & 14,35 & 9,80 & 46,00 & 6,67 & 2,30 & 5,63 \\
\hline 120 & 10,11 & 9,65 & 31,75 & 4,75 & 3,50 & 3,93 \\
\hline 150 & 10,85 & 8,40 & 34,50 & 4,75 & 2,13 & 4,73 \\
\hline
\end{tabular}

Tabela 6. Teores de macronutrientes em partes aéreas de plantas de carqueja var. CPQBA-1 cultivadas em vasos em casa de vegetação durante 150 dias, com poda no dia de transplantio. Araraquara, SP, 2009.

\begin{tabular}{|c|c|c|c|c|c|c|}
\hline \multirow{3}{*}{$\begin{array}{l}\text { Dias após } \\
\text { transplantio }\end{array}$} & \multicolumn{6}{|c|}{ Macronutrientes } \\
\hline & $\mathrm{N}$ & $\mathrm{P}$ & $\mathrm{K}$ & $\mathrm{Ca}$ & $\mathrm{Mg}$ & $\mathrm{S}$ \\
\hline & \multicolumn{6}{|c|}{ 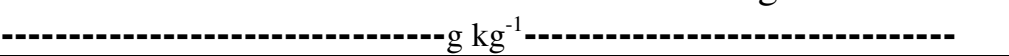 } \\
\hline 30 & 8,22 & 1,95 & 19,75 & 6,50 & 2,13 & 1,80 \\
\hline 60 & 7,59 & 3,45 & 32,00 & 5,75 & 2,30 & 4,58 \\
\hline 90 & 12,72 & 4,08 & 38,50 & 8,00 & 3,15 & 1,95 \\
\hline 120 & 9,07 & 3,75 & 33,75 & 8,00 & 2,88 & 1,65 \\
\hline 150 & 2,84 & 3,85 & 29,25 & 6,75 & 2,93 & 2,13 \\
\hline
\end{tabular}


Tabela 7. Teores de macronutrientes em raízes de plantas de carqueja var. CPQBA-1 cultivadas em vasos em casa de vegetação durante 150 dias, com poda no dia de transplantio. Araraquara, SP, 2009.

\begin{tabular}{|c|c|c|c|c|c|c|}
\hline \multirow{3}{*}{$\begin{array}{l}\text { Dias após } \\
\text { transplantio }\end{array}$} & \multicolumn{6}{|c|}{ Macronutrientes } \\
\hline & $\mathrm{N}$ & $\mathrm{P}$ & $\mathrm{K}$ & $\mathrm{Ca}$ & $\mathrm{Mg}$ & $\mathrm{S}$ \\
\hline & \multicolumn{6}{|c|}{ - } \\
\hline 30 & 3,39 & 2,58 & 17,25 & 6,00 & 2,95 & 2,23 \\
\hline 60 & 8,94 & 2,60 & 25,75 & 6,00 & 2,03 & 2,85 \\
\hline 90 & 11,28 & 8,78 & 34,75 & 9,25 & 3,13 & 3,78 \\
\hline 120 & 8,45 & 7,85 & 35,00 & 6,75 & 2,30 & 3,78 \\
\hline 150 & 9,85 & 7,93 & 27,25 & 5,50 & 2,73 & 4,25 \\
\hline
\end{tabular}

\subsubsection{Nitrogênio}

A Figura 5 representa as curvas de regressão referentes ao acúmulo de nitrogênio obtidos durante os 150 dias de cultivo. Apesar da Figura 5C não ter apresentado dados significativos que permitissem a elaboração da curva de regressão, verificou-se que o acúmulo de $\mathrm{N}$ foi ascendente desde o início até o final do cultivo, demonstrando a necessidade deste nutriente para o desenvolvimento desta espécie.
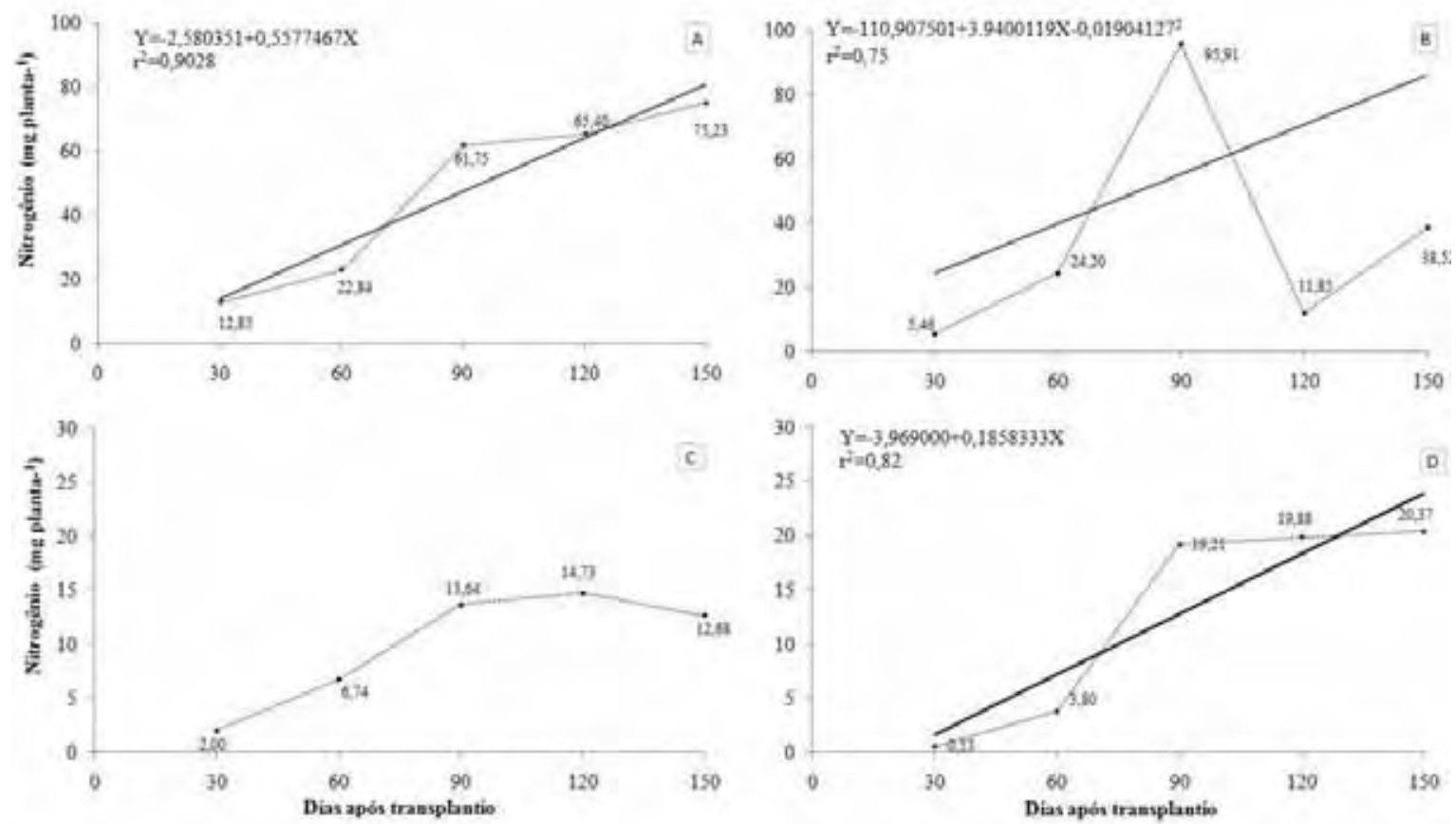

Figura 5. Acúmulo de nitrogênio em plantas de carqueja var. CPQBA-1 cultivadas em vasos em casa de vegetação durante 150 dias. (A): Parte aérea - sem poda no transplantio; (B): Parte aérea - com poda no transplantio; (C) Raiz - sem poda no transplantio; (D) Raiz - com poda no transplantio. FCF/UNESP. Araraquara, SP, 2009. 
$\mathrm{O}$ acúmulo de $\mathrm{N}$ nas partes aéreas de ambos os sistemas de cultivo, superaram àquele verificado nas raízes em aproximadamente 5 vezes durante todo o ciclo observado, o que demonstrou uma possível translocação do nutriente das raízes para as partes aéreas durante todo o período avaliado.

As plantas assimilaram menores teores no início do cultivo, mostrando similaridade com a maioria das culturas anuais (MALAVOLTA, 1980), que foi seguido de um acréscimo, provavelmente, causado pelas exigências deste nutriente pelas plantas devido ao desenvolvimento notado na produção de matéria seca, e supridos, provavelmente pelas adubações de cobertura.

O período de máxima velocidade de absorção do nitrogênio correspondeu ao período de grande acúmulo diário de matéria seca, entre 60 e 90 dias, provavelmente período de alta taxa de assimilação fotossintética, demonstrando que a carqueja, não absorve todo o nitrogênio que necessita nos primeiros 50 dias, hipótese reforçada em outras culturas mais estudadas como o feijão (ROSOLEM, 1987) e arroz (BARBOSA FILHO, 1987).

Apesar das curvas serem similares àquelas que descrevem a produção de matéria seca, a perda relativa de nitrogênio a partir dos 90 até os 150 dias, foi maior do que a perda de matéria seca, atingido a menor concentração nos 120 DAT, tornando aparente a necessidade deste nutriente que não foi suprida pelas quantidades presentes no solo, ou mesmo a diluição do nutriente, causada pelo crescimento brusco da planta (Tabela 3). Primavesi (2002) relata que esse efeito de diluição não precisa, necessariamente, acusar uma absorção deficiente de nutrientes, mas pode indicar um intenso crescimento. Independente da causa, a queda de $\mathrm{N}$ teve proporções significativas, e uma melhor compreensão dos processos envolvidos levará a uma maior eficiência no uso deste nutriente.

Observou-se, ainda, que ao final dos 150 dias de cultivo, as plantas que não receberam a poda no transplantio, apresentaram acumulo de 75,2 $\mathrm{g} \mathrm{planta}^{-1}$ de $\mathrm{N}$, já as que receberam a poda, acumularam 38,5 $\mathrm{g}_{\text {planta }}{ }^{-1}$, o que demonstrou novamente um possível efeito de diluição, já que as plantas que receberam poda acumularam mais matéria seca ao final do ciclo, em comparação às que não receberam poda. Os teores de $\mathrm{N}$ acumulados nesta variedade de carqueja foram inferiores aos obtidas por Cortés et al. (2007) ao estudarem a 
cultura da carqueja $\left(17,20 \mathrm{~g} \mathrm{~kg}^{-1}\right)$ e por Marcussi (2005) ao estudar a cultura do pimentão $\left(28,3 \mathrm{~g} \mathrm{~kg}^{-1}\right)$.

De modo geral, as curvas de acúmulos de $\mathrm{N}$ podem subsidiar algumas recomendações para futuras pesquisas e plantios. Ao considerar as diferentes taxas de fornecimento de $\mathrm{N}$ de cada solo e supondo as possíveis perdas por lavagem ou fixação entre outros fatores, recomenda-se para a variedade CPQBA-1 uma adubação organo-mineral, fornecendo uma adubação nitrogenada, no dia do transplantio, por exemplo com esterco de galinha, executando duas adubações de cobertura com N, a primeira aos 50 e a segunda aos 90 dias após transplantio. As fontes e doses dependerão das condições físico-químicas de cada solo e dos objetivos e condições econômicas do produtor rural.

\subsubsection{Fósforo}

A Figura 6 demonstra um acúmulo crescente de fósforo durante os 150 dias de cultivo, que apesar das oscilações, as curvas de regressão expressaram claramente a exigência ascendente da absorção de $\mathrm{P}$ para esta espécie e, mais especificamente desta variedade. $\mathrm{O}$ fósforo é um nutriente importante no armazenamento de energia e na integridade estrutural das plantas (Taiz \& Zeiger, 2006) e, portanto, é considerado essencial no reino vegetal, e não menos essencial para carqueja.

$\mathrm{O}$ acúmulo de $\mathrm{P}$ ocorreu em quantidades inferiores comparativamente ao de $\mathrm{N}$, apesar das curvas apresentarem semelhanças quanto às tendências crescentes durante todo o ciclo e, principalmente quanto ao maior acúmulo ter ocorrido a partir dos 90 DAT e coincidente à queda ocorrida nas raízes durante os últimos 30 dias de cultivo. Estas respostas evidenciaram necessidades reais para ambos os nutrientes em períodos parecidos. Esta observação concorda com Malavolta (1980).

Nos primeiros 30 DAT notou-se um baixo acúmulo de $\mathrm{P}$ nas raízes e partes aéreas das plantas em ambos os sistemas de cultivo, evidenciando uma baixa exigência de fósforo nas fases iniciais do cultivo, porém fundamental na adaptação das mudas ao novo ambiente, demandando $\mathrm{P}$ para dar continuidade nos processo de desenvolvimento de raízes e novas brotações.

O período entre 30 e 60 DAT revelou acumulo crescente de fósforo nas raízes das plantas que não receberam poda no transplantio, fato não ocorrido nas raízes 
plantas que receberam a poda. Inferiu-se que neste período parte do fósforo presente ou acrescido ao solo via adubação orgânica ou mineral, tenha sido adsorvido por oxidróxidos de ferro e alumínio, conforme descrito por Novais et al. (2007). Possivelmente foi absorvido pelas plantas apenas o fósforo presente na sua forma disponível. Desta forma, supõe-se que os teores de P-disponível tenham suprido as necessidades iniciais das plantas que não receberam poda, promovendo o crescimento das mesmas (Figura 4). As plantas que receberam poda, provavelmente, também absorveram e metabolizaram este P-disponível, porém se acredita que as necessidades de $\mathrm{P}$ diárias foram maiores devido à demanda energética das plantas para as emissões das brotações. Após este aporte do P-disponível, acredita-se que houve a disponibilização do $\mathrm{P}$ menos adsorvido aos oxidróxidos, ou mesmo pelos altos teores de matéria orgânica presentes neste solo, que podem ter favorecido a ciclagem do $\mathrm{P}$ aumentando a sua disponibilidade às plantas. Conforme Andrade et al. (2003), hipótese notável na recuperação da ascendência da curva de acúmulo de $\mathrm{P}$ e quantidades de matéria seca a partir dos 60 DAT, conforme mostrado na Figura 6D.
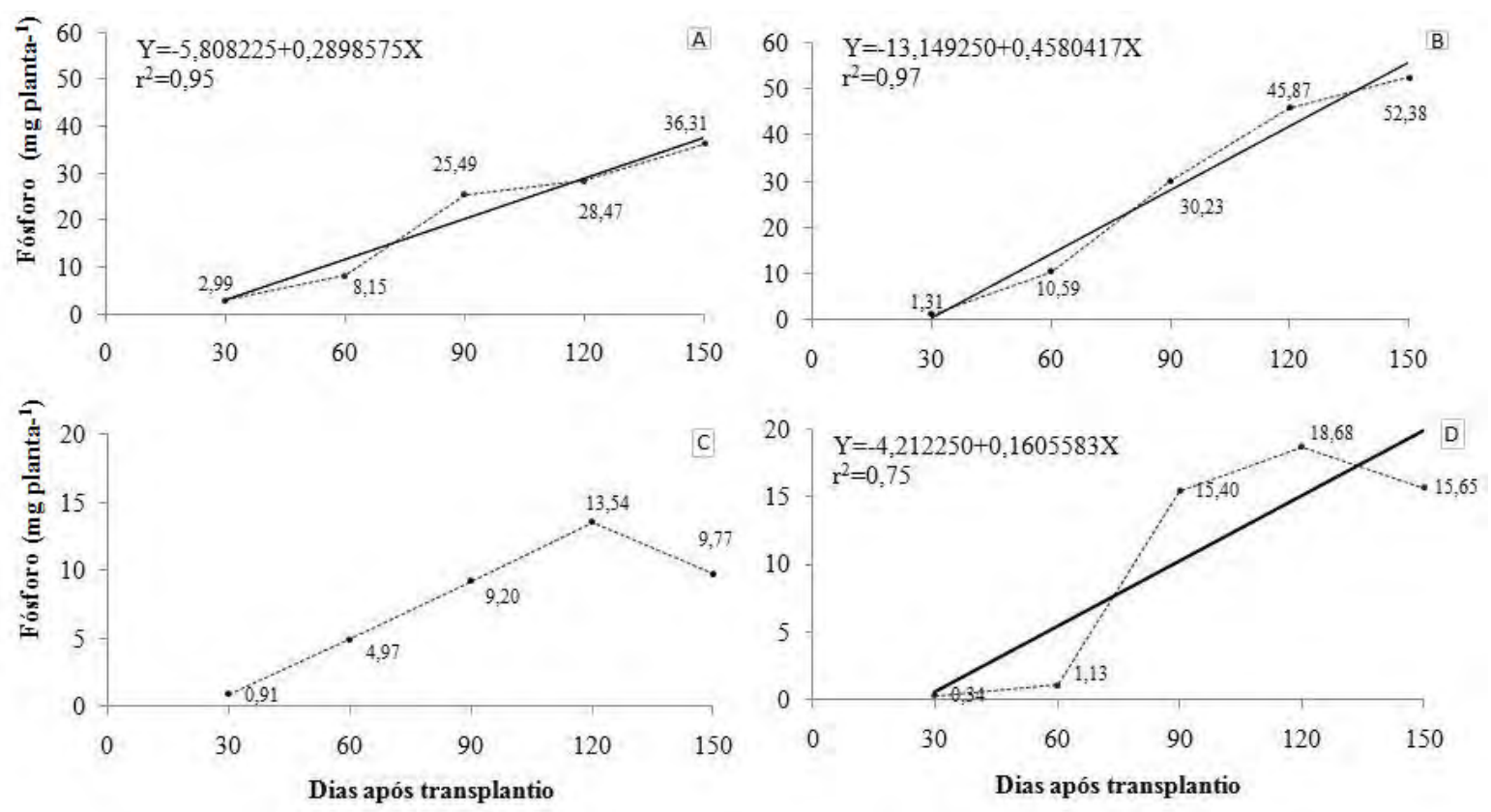

Figura 6. Acúmulo de fósforo em plantas de carqueja var. CPQBA-1 cultivadas em vasos em casa de vegetação durante 150 dias. (A): Parte aérea - sem poda no transplantio; (B): Parte aérea - com poda no transplantio; (C) Raiz - sem poda no transplantio; (D) Raiz - com poda no transplantio. FCF/UNESP. Araraquara, SP, 2009. 
Aos 120 DAT notou-se a queda no acúmulo de $\mathrm{P}$ nas raízes das plantas; tendência semelhante para os teores de matéria seca. Tal fato não foi observado nas partes aéreas das plantas, o que sugere uma translocação deste nutriente para as partes aéreas, talvez em resposta a uma ausência de P no solo para suprir a demanda desta variedade neste período de cultivo.

\subsubsection{Potássio}

As curvas de acúmulo de potássio nesta variedade de carqueja demonstradas na Figura 7 evidenciaram diferenças no padrão de absorção em relação aos outros macronutrientes, principalmente nitrogênio e fósforo.
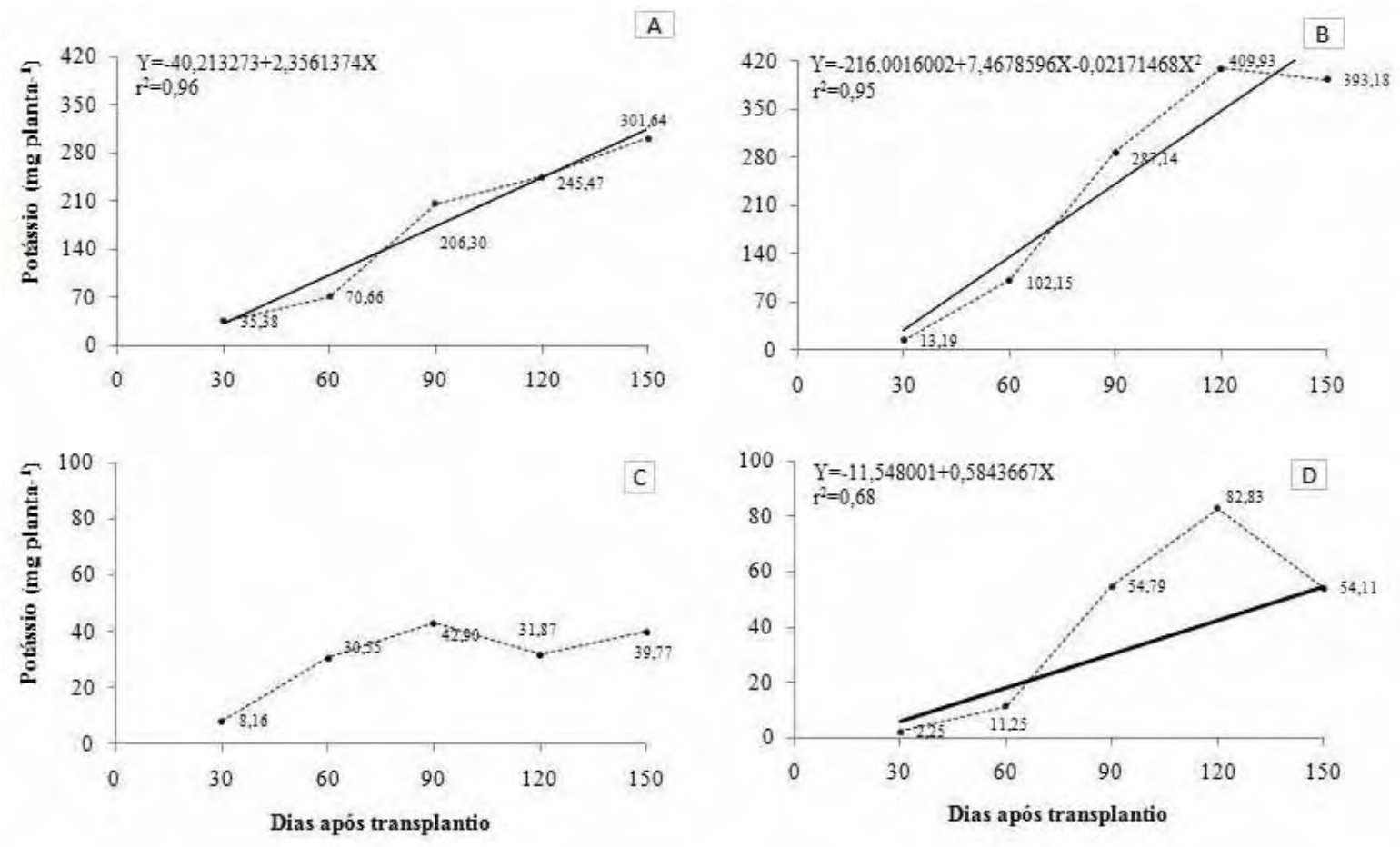

Figura 7. Acúmulo de potássio em plantas de carqueja var. CPQBA-1 cultivadas em vasos em casa de vegetação durante 150 dias. (A): Parte aérea - sem poda no transplantio; (B): Parte aérea - com poda no transplantio; (C) Raiz - sem poda no transplantio; (D) Raiz - com poda no transplantio. FCF/UNESP. Araraquara, SP, 2009.

O acúmulo foi expressivamente maior para este nutriente, fato confirmado por Malavolta (2006) ao citar que o K é o cátion mais abundante nas plantas. Segundo Castro et al. (2005), este íon ativa mais de 50 enzimas nos vegetais e é responsável 
pela abertura e fechamento de estômatos. Os altos teores encontrados neste experimento são corroborados pelos teores relatados por Sousa (2005) e por Cortés et al. (2007) ao estudarem a cultura da carqueja. Tais constatações indicam a exigência de potássio por esta variedade. Segundo Malavolta et al. (1997) dentre os principais nutrientes ligados ao aumento da produtividade, o $\mathrm{K}$ é, em média, o segundo elemento mais abundante na matéria seca das plantas, quando se consideram os macronutrientes essenciais.

Nos primeiros 30 dias após o transplantio, as plantas que não receberam poda apresentaram um teor de $17,25 \mathrm{~g} \mathrm{~kg}^{-1}$ de $\mathrm{K}$ nas partes aéreas, conforme mostrado na Tabela $4 \mathrm{e}$ as plantas que receberam poda apresentaram 19,75 $\mathrm{g} \mathrm{kg}^{-1}$ conforme Tabela 6. A partir da primeira coleta, os níveis aumentaram cerca de $60 \%$ em ambos sistemas de manejo. Essa tendência também foi observada nas raízes, porém, em maiores proporções. Tais aumentos nos níveis de $\mathrm{K}$ podem indicar a necessidade deste nutriente no início do cultivo, a qual, provavelmente, foi suprida pelo $\mathrm{K}$ disponível no solo, todavia, verificou-se uma ascendência contínua das curvas, provavelmente, causada pelas adubações de cobertura.

Os teores médios de $\mathrm{K}$ durante todo o ciclo foram em torno de $28 \mathrm{~g} \mathrm{~kg}^{-}$ 1, os quais foram semelhantes aos obtidos por Lima Filho et al. (1997) ao estudarem a absorção e a acumulação de macronutrientes em estévia cultivada em campo, sob sistema comercial de cultivo.

Ainda na Figura 7, observou-se respostas similares entre as partes das plantas (parte aérea e raiz) que receberam o mesmo tratamento de transplantio, o que pode ser mais claramente visualizado na Figura 7A e 7C, no aumento das quantidades de K até os 90 DAT e na Figura 7B e 7D, no acúmulo lento até os 60 dias, seguido de acúmulo ascendente até os 120 DAT. Em ambos os casos, os acúmulos foram maiores nas raízes do que nas partes aéreas, sugerindo uma baixa taxa de translocação do $\mathrm{K}$ das raízes para as parte superior das plantas, hipótese reforçada por Malavolta (2006), onde ressalta que, em geral, as raízes contém cerca de $16 \%$ do total de $\mathrm{K}$ da planta.

A partir dos 105 DAT observou-se uma queda generalizada nos acúmulos de $\mathrm{K}$, fato que pode ser analisado ao se comparar os gráficos da Figura 7, com os gráficos de matéria seca representados na Figura 4, demonstrando claramente um crescimento acirrado da planta, até se estabilizar nos 135 DAT. Tal fato pode ter sido responsável por uma demanda excessiva da planta por K, não suprida pelo solo ou ineficiência de absorção pelo 
sistema radicular causado por características desta variedade de carqueja ou mesmo pela inibição competitiva causada pelos altos teores de Ca presentes neste solo.

Tais fatos consolidam a necessidade da adubação potássica na cultura da carqueja, evidenciando as maiores exigências no início e após os 90 DAT. Todavia, vale salientar que os excessos de potássio no meio, devido a inibição competitiva na absorção de nutrientes citada por Malavolta (1986; 2006), poderão causar deficiência de Ca e Mg, os quais deverão estar presentes no solo em proporções ideais com as quantidades de K.

\subsubsection{Cálcio}

A Figura 8 demonstra com a análise de regressão, a resposta ascendente das plantas quanto à absorção de $\mathrm{Ca}$, tanto nas raízes quanto nas partes aéreas. Esta tendência demonstrou que esta espécie parece se exigente em $\mathrm{Ca}$, apresentando acúmulo semelhante ao de $\mathrm{N}$ e superior ao de $\mathrm{P}$, fato que confirma a essencialidade da presença deste nutriente para o cultivo desta variedade. Neste caso, não foi necessário a realização da calagem, mas para futuras recomendações, os resultados aqui apresentados conflitam com os obtidos por De Bona (2002) ao citar que esta espécie se desenvolve melhor em solos com baixa saturação por bases em torno de $44 \%$, sugerindo que novos estudos a respeito de Ca e V\% sejam realizados com esta espécie e principalmente com esta variedade.

Os gráficos da Figura 8 evidenciam uma translocação ascendente deste nutriente das raízes para as partes aéreas, ao apresentar maiores acúmulos nas partes aéreas das plantas do que nas raízes.

Ao analisar os teores de $\mathrm{Ca}$, nas Figuras 4, 5, 6 e 7, nota-se uma tendência retilínea, sem muitas oscilações entre as diferentes partes das plantas, evidenciando a necessidade constante deste nutriente, o que pode ser confirmado observando-se as médias gerais dos teores apresentados durante os 150 dias de cultivo: parte aérea e raiz sem poda 7,65

$\mathrm{g} \mathrm{kg}^{-1}, 5,58 \mathrm{~g} \mathrm{~kg}^{-1}$ e parte aérea e raiz com poda $7,00 \mathrm{~g} \mathrm{~kg}^{-1}, 6,70 \mathrm{~g} \mathrm{~kg}^{-1}$, respectivamente.

Outra característica relevante quanto às respostas da planta à absorção do $\mathrm{Ca}$, é a sua relação com a absorção de $\mathrm{K}$ e $\mathrm{Mg}$. No decorrer deste experimento, próximo à data da segunda adubação, notou-se a descoloração das alas foliares, tornando-as com tons verdes esbranquiçados (Figura 9). 

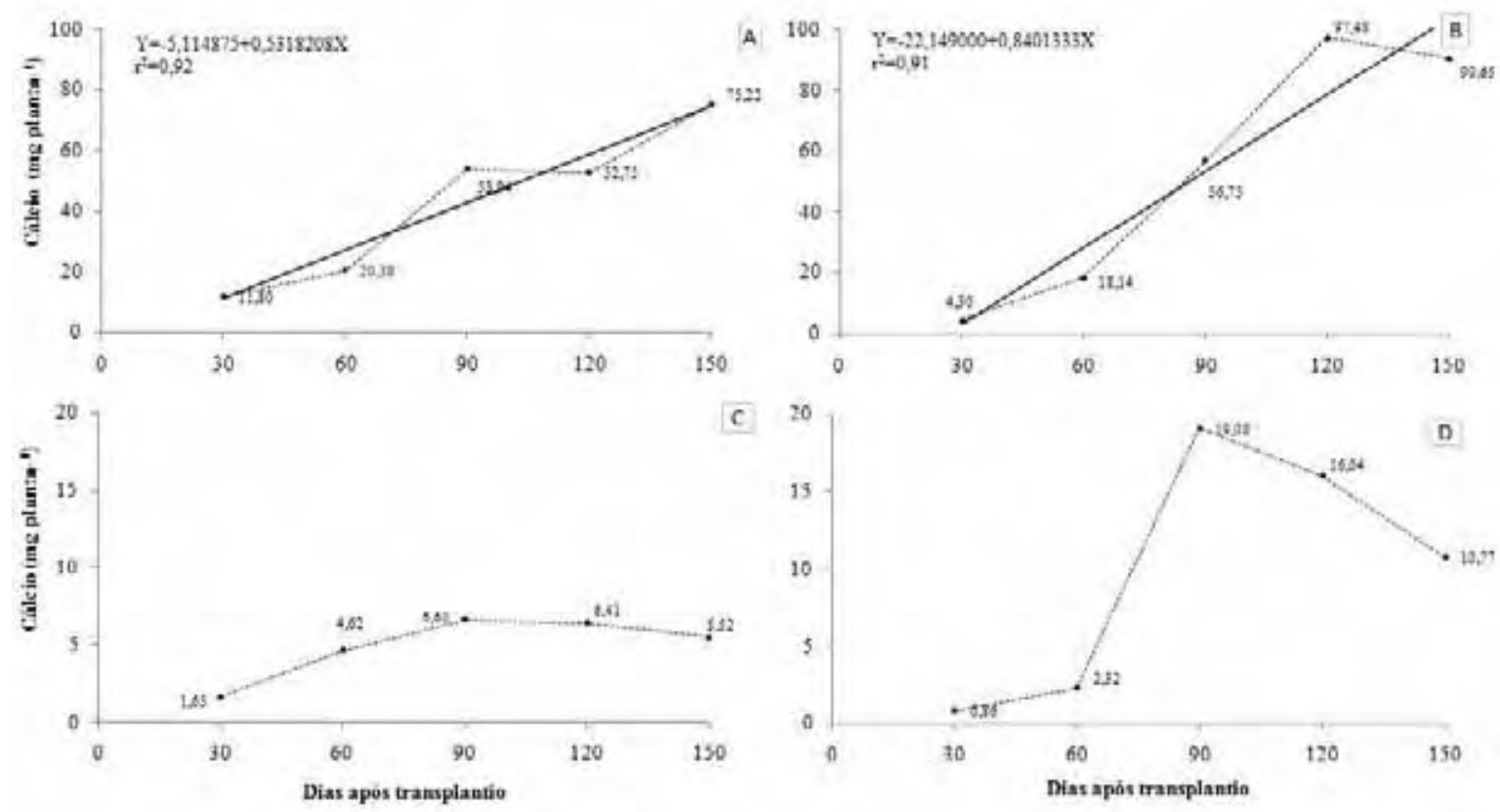

Figura 8. Acúmulo de cálcio em plantas de carqueja var. CPQBA-1 cultivadas em vasos em casa de vegetação durante 150 dias. (A): Parte aérea - sem poda no transplantio; (B): Parte aérea - com poda no transplantio; (C) Raiz - sem poda no transplantio; (D) Raiz - com poda no transplantio. FCF/UNESP. Araraquara, SP, 2009.

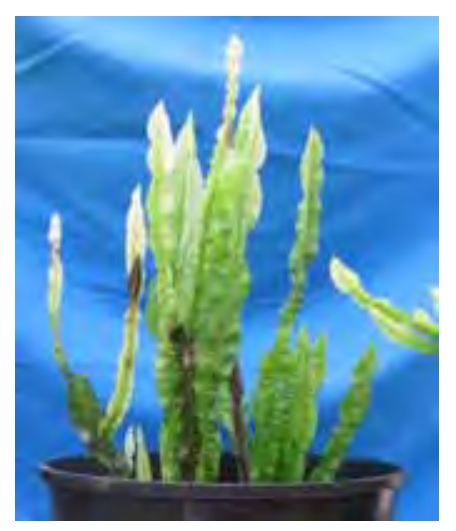

Figura 9. Descoloração das alas foliares de carqueja var. CPQBA-1 cultivada em vaso em casa de vegetação. FCF/UNESP. Araraquara, SP, 2009.

Após descartar a possibilidade dos sintomas apresentados nas plantas estarem relacionados ao ataque de pragas ou doenças, realizou-se a adubação com o nitrato de cálcio e fosfato de potássio. Após alguns dias, notou-se a recuperação da coloração verde viçosa característica da espécie. Uma possível explicação para este ocorrido pode ser referente 
aos mecanismos de absorção iônica pelas raízes. Segundo Malavolta (2006) a absorção de um dado elemento pode ser influenciada pela presença de outro. Neste caso, o Ca aplicado na adubação pode ter sido inibido pela presença do $\mathrm{Mg}$ que, possivelmente, se ligou no mesmo sítio do carregador para cruzar a membrana. Assim o Mg principal elemento da composição da clorofila, pode ter sido absorvido pelas raízes possibilitando a síntese de clorofila nas partes cloróticas, reativando os processos metabólicos da fotossíntese, deixando a planta verde novamente. Esta explicação, também pode ser complementada pela velocidade de absorção dos íons, em que neste caso o ânion $\mathrm{NO}^{3-}$ e o cátion $\mathrm{Mg}^{2+}$ seriam mais rapidamente absorvidos do que o cátion $\mathrm{Ca}^{2+}$, conforme ordem de absorção citada por Malavolta (2006). Outra sugestão para a observação constatada neste período pode ser em relação ao efeito sinérgico na absorção dos nutrientes, o qual concentrações moderadas de Ca aumentam a absorção dos cátions em geral (MALAVOLTA, 2006), facilitando, assim, a absorção do Mg. Estas possibilidades clássicas sugerem que novas pesquisas sejam realizadas, e possibilitem uma melhor compreensão deste ocorrido e, se possível, possibilite soluções para novos plantios de carqueja.

\subsubsection{Magnésio}

Na Figura 10 observa-se que a variedade CPQBA-1 não é muito exigente neste nutriente, não ausentando um reforço nem atenção para a presença deste nutriente em solos a serem cultivados com carqueja. As curvas com maior acúmulo nas partes aéreas demonstram uma translocação do nutriente das raízes para as partes aéreas, evidenciada sobretudo nos Gráficos B e D da Figura 10.

Apesar dos baixos teores observados na Figura 10, este elemento foi absorvido pelas raízes logo nos primeiros 30 DAT, o que demonstrou que as quantidade de Mg disponíveis no solo foram aproveitadas pelas plantas.

As oscilações no acúmulo de Mg observadas nas raízes (Figura 10C e 10D) sugerem possíveis contaminações na amostragem, devido aos resíduos de solo presos às radicelas. Já oscilação do acúmulo deste nutriente nas partes aéreas, apresentados na Figura 10A e 10B, sugerem diferenças ocorridas na amostragem para elaboração das análises foliares, pois apesar das amostras serem compostas pelas alas foliares estas foram moídas e homogeneizadas, todavia existe a probabilidade de algumas amostras terem sido compostas 
por maior quantidade de alas foliares e outras de caules. Alquini e Takemori (2000) citam que ambos as partes possuem parênquima clorofiliano, todavia as alas possuem maior área de superfície e por sua vez, tendem a realizar mais fotossíntese, favorecendo maior acúmulo de Mg. Com esta hipótese sugere-se que novos estudos para quantificação de Mg nas partes aéreas sejam feitos, separando-se as alas foliares dos caules.
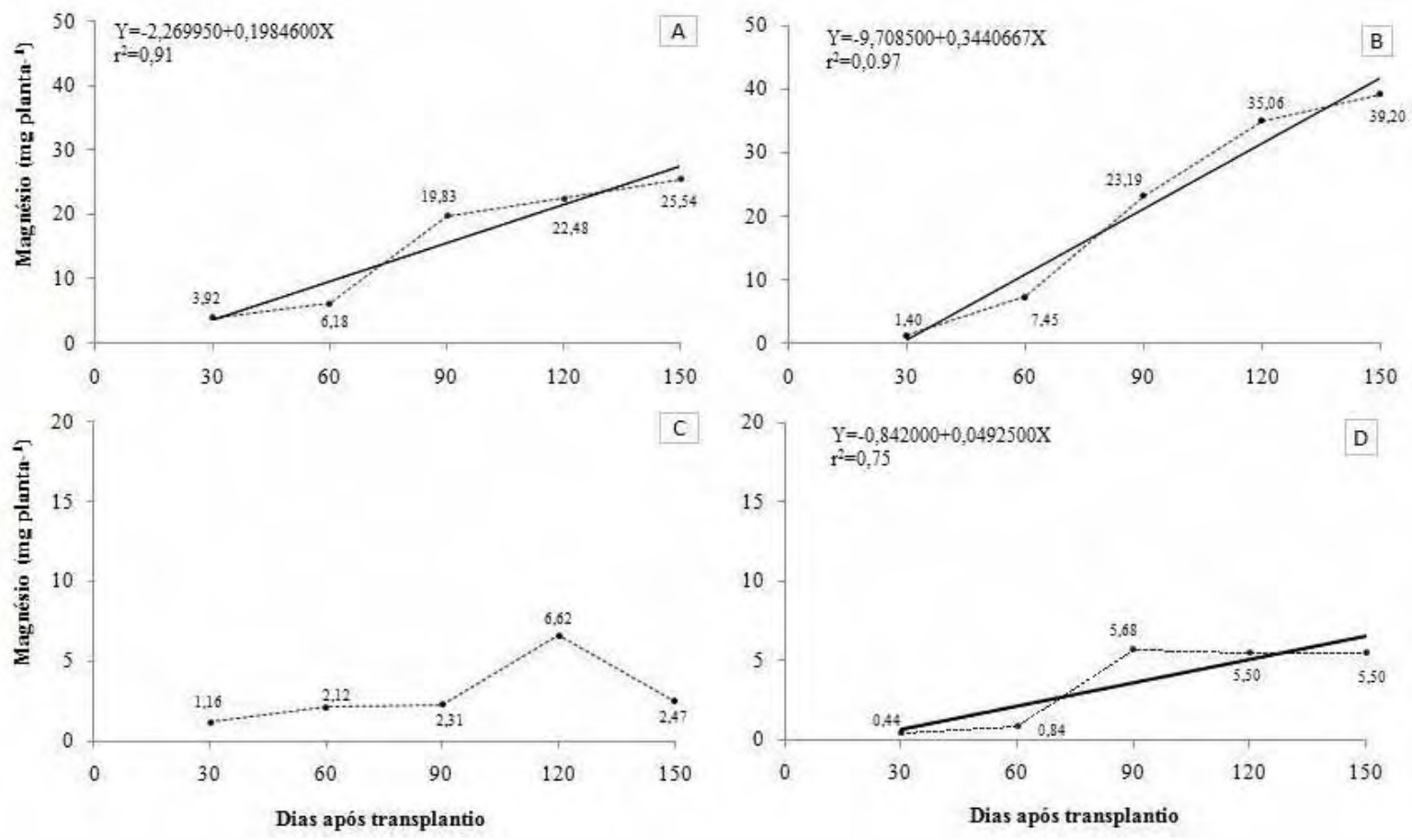

Figura 10. Acúmulo de magnésio em plantas de carqueja var. CPQBA-1 cultivadas em vasos em casa de vegetação durante 150 dias. (A): Parte aérea - sem poda no transplantio; (B): Parte aérea - com poda no transplantio; (C) Raiz - sem poda no transplantio; (D) Raiz - com poda no transplantio. FCF/UNESP. Araraquara, SP, 2009.

\subsubsection{Enxofre}

O enxofre juntamente com o magnésio, foi um dos macronutrientes encontrado em menores quantidades nas plantas de carqueja var. CPQBA-1. O baixo acúmulo de $\mathrm{S}$ contidos nos tecidos vegetais, também foram citados por Malavolta (1980) para as principais culturas. O mesmo foi observado em culturas não convencionais, como em rami (HIRACE et al., 1985) e em estévia (LIMA FILHO et al., 1997).

Nota-se na Figura 11, que os acúmulos de $\mathrm{S}$ não superaram nas raízes o valor máximo de 8,94 $\mathrm{g}_{\text {planta }}{ }^{-1}$ e nas partes aéreas o valor máximo de 28,75 g planta $^{-1}$. Este 
fato, demonstrou que esta variedade pode não ser muito exigente neste nutriente apesar de apresentar translocação deste nutriente das raízes para as partes aéreas, fato corroborado por Malavolta (1980), que relatou que o S, principalmente na forma de sulfato, é transportado predominantemente na direção acróptera, da base da planta para cima, sendo muito pequena a capacidade da planta deslocar o enxofre na direção basípeta.

Os picos de teores de enxofre estão entre os 60 e 90 dias, mais acentuados nas plantas que sofreram poda no transplantio (Figura 11B e 11D), provavelmente, decorrente da adubação de cobertura contendo sulfato.

Os macronutrientes aniônicos N, P e S representados nas Figuras 5, 6 e 11, respectivamente, apresentaram curvas de regressão semelhantes entre si e correlatos aos citados por Malavolta (1980) para as principais culturas. As exigências de $\mathrm{N}$ foram algumas vezes maiores que as de $\mathrm{P}$ e $\mathrm{S}$ e as necessidades de $\mathrm{P}$ e $\mathrm{S}$ foram muito parecidas, tanto nas plantas que não receberam poda no transplantio, quanto nas que foram submetidas a esta prática.
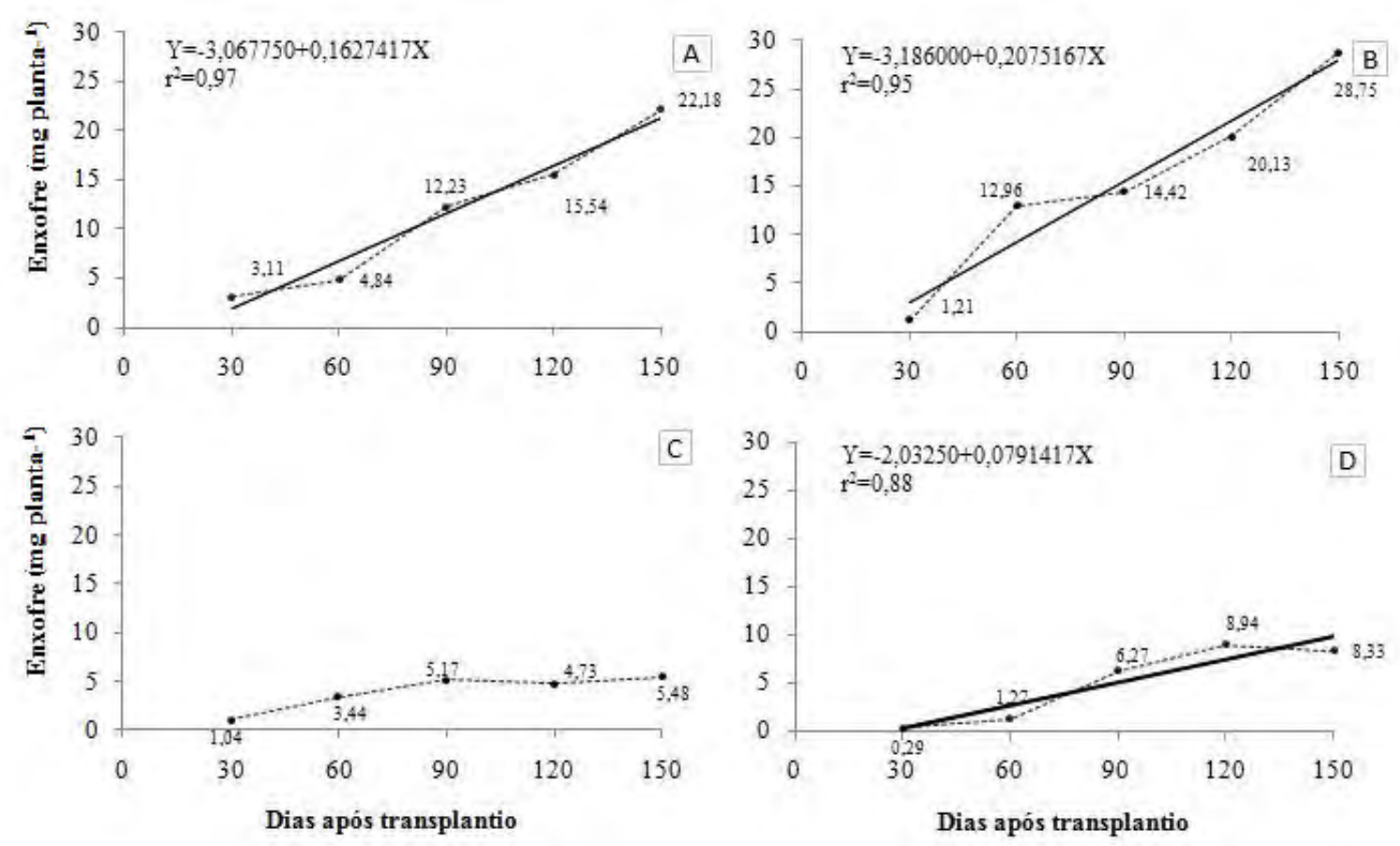

Figura 11. Acúmulo de enxofre em plantas de carqueja var. CPQBA-1 cultivadas em vasos em casa de vegetação durante 150 dias. (A): Parte aérea - sem poda no transplantio; (B): Parte aérea - com poda no transplantio; (C) Raiz - sem poda no transplantio; (D) Raiz - com poda no transplantio. FCF/UNESP. Araraquara, SP, 2009. 


\subsection{Teor e acúmulo de fenólicos totais}

As plantas de carqueja var. CPQBA-1 apresentaram curvas de acúmulo de compostos fenólicos totais ascendentes durante todo o período de cultivo, conforme mostrado na Figura 12. A acumulação variou entre $0,633 \mathrm{mg} \mathrm{planta}^{-1}$ e 2,879 $\mathrm{mg}_{\text {planta }}{ }^{-1}$ nas que não receberam poda e $0,180 \mathrm{mg} \mathrm{planta}^{-1} \mathrm{e} 3,170 \mathrm{mg} \mathrm{planta}^{-1}$ nas que receberam poda.

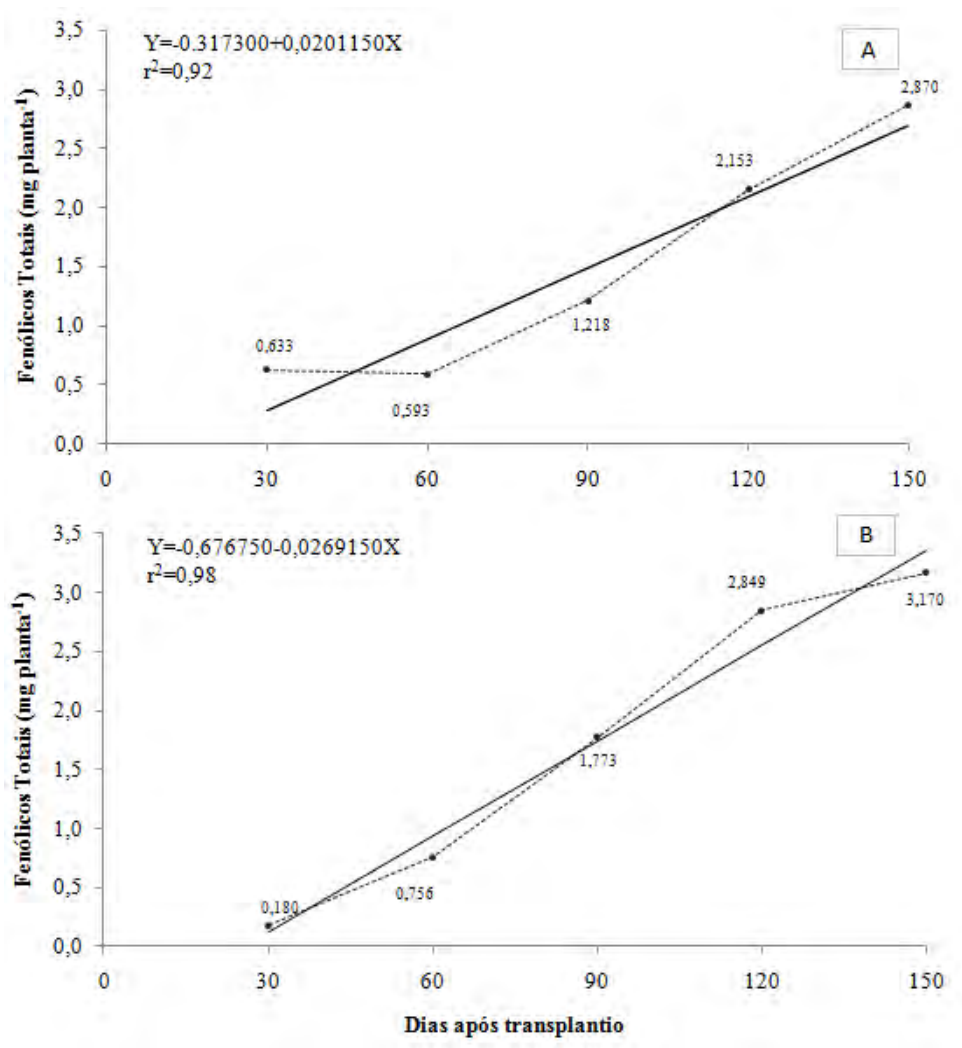

Figura 12. Acúmulo de compostos fenólicos totais em plantas de carqueja var. CPQBA-1 cultivadas em vasos em casa de vegetação durante 150 dias. (A): Parte aérea - sem poda no transplantio; (B): Parte aérea - com poda no transplantio. FCF/UNESP. Araraquara, SP, 2009

Os teores variaram entre 0,2 e $0,3 \mathrm{~g} \mathrm{~kg}^{-1}$, conforme mostrado na Tabela 8. As Plantas que não receberam poda no transplantio apresentaram teores médios de $0,262 \mathrm{~g}$ $\mathrm{kg}^{-1}$ e as que sofreram poda, $0,242 \mathrm{~g} \mathrm{~kg}^{-1}$ ao longo do período de cultivo. Esta semelhança entre os teores permaneceram até a data da última coleta, a qual os teores nas plantas intactas superaram os teores nas que receberam poda em $0,039 \mathrm{~g} \mathrm{~kg}^{-1}$. No entanto, a Figura 12, ao expressar o acúmulo de fenólicos totais em $\mathrm{mg} \mathrm{planta}^{-1}$, demonstrou que as plantas que 
receberam poda, acumularam quantidades superiores às plantas intactas, durante quase todo o ciclo, superando em $0,3 \mathrm{mg}$ planta $^{-1}$ somente na última coleta. Este fato sugeriu que o manejo com poda, possa induzir e desencadear a produção de metabólitos secundários e, mais especificamente de compostos fenólicos. Mcconchie et al. (1994), ressaltam que condições de estresse podem influenciar na produção de fenóis, assim como na liberação de polifenóis dos vacúolos.

Tabela 8. Teores de compostos fenólicos totais e produção de matéria seca em partes aéreas de plantas de carqueja var. CPQBA-1 cultivadas em vasos em casa de vegetação durante 150 dias, sem e com poda no dia de transplantio. Araraquara, SP, 2009.

\begin{tabular}{|c|c|c|c|c|}
\hline \multirow{2}{*}{$\begin{array}{l}\text { Dias após } \\
\text { transplantio }\end{array}$} & \multicolumn{2}{|c|}{ Compostos Fenólicos Totais } & \multicolumn{2}{|c|}{ Matéria Seca } \\
\hline & Sem Poda & Poda & Sem Poda & Com Poda \\
\hline 30 & 0,309 & 0,273 & 2,04 & 0,66 \\
\hline 60 & 0,232 & 0,247 & 2,54 & 2,96 \\
\hline 90 & 0,229 & 0,237 & 5,30 & 7,46 \\
\hline 120 & 0,273 & 0,226 & 7,76 & 12,37 \\
\hline 150 & 0,265 & 0,226 & 10,65 & 13,40 \\
\hline
\end{tabular}

As diferenças entre os teores de fenólicos totais em plantas que receberam poda no transplantio (Figura 12B) não foram significativas, no entanto, esta curva permitiu a interpretação biológica das respostas demonstradas por esta variedade. Neste caso, acredita-se que a variabilidade genética ainda restante nesta variedade, já mencionada anteriormente, possa ter se expressado com maior intensidade nas plantas que receberam poda, hipótese reforçada pela não significância dos dados referentes aos teores de fenólicos totais.

Os teores médios de fenólicos totais obtidos neste trabalho variaram entre $0,02 \%$ a $0,03 \%$ e foram inferiores aos encontrados por Silva et al. (2007), que ao estudarem a mesma espécie, porém trabalhando com plantas silvestres, obtiveram teores de fenólicos totais entre 3,26 a 7,32\% em populações silvestres e cultivadas. Os teores obtidos por Silva et al. (2007), também foram superiores aos obtidos por Freitas et al. (2004), que obtiveram em média 2,38\% ao estudarem a mesma espécie cultivada em casa de vegetação sob duas condições de adubação e 5 inoculações com fungos micorrízicos. Castro et al. (1999) analisaram os teores de taninos expressos em fenólicos totais em populações de $B$. 
myriocephala e obtiveram valores muito variáveis, entre $0,26 \%$ e $12,18 \%$ durante 5 coletas realizadas em 229 dias de cultivo.

Os teores de fenólicos obtidos neste trabalho, notadamente inferiores aos citados acima, inferiram uma possível relação com as diferentes metodologias utilizadas nas determinações dos fenólicos totais, pois ambos utilizaram o reagente Folin-Denis e para construção da curva padrão utilizaram o ácido tânico, diferindo deste trabalho o qual utilizouse o reagente Folin-Ciocalteau e o ácido gálico na curva padrão. Segundo Singleton \& Rossi (1965) o reagente Folin-Ciocalteau apresenta maior sensibilidade e reprodutibilidade nas análises de compostos fenólicos. Appel et al. (2001) ressaltaram que o reagente Folin-Denis não reproduz quantificações relativas ou absolutas confiáveis de compostos fenólicos quando diferentes amostras de datas divergentes são comparadas. Singleton et al. (1999) citaram inúmeras vantagens para a utilização do acido gálico na construção da curva padrão, sendo este solúvel em água, recristalizado facilmente da água, seco rapidamente, estável na forma seca e mais barato do que o acido tânico, apesar de ressaltarem que em análises realizadas com vinho, ambos apresentam valores muito similares.

Silva et al. (2006) ao extraírem e quantificarem as flavonas 5,3'diidróxi-4',6,7-trimetóxiflavona e 5-hidroxi-3',4',6,7-tetrametóxiflavona em populações de $B$. trimera utilizando a cromatografia líquida de alta eficiência obtiveram teores médios de $0,025 \%$ e $0,0008 \%$, respectivamente. Apesar de estes pesquisadores terem estudado uma flavona padronizada, os valores encontrados foram semelhantes aos obtidos neste trabalho. No entanto, Sousa et al. (2007) ao estudarem os teores de compostos fenólicos em cinco plantas medicinais de ocorrência natural no estado do Piauí, obtiveram valores bem maiores do que os obtidos neste trabalho, apesar de utilizarem a mesma metodologia de análise, com exceção da extração etanólica, os próprios autores, ao compararem com a literatura, concluíram que estas espécies são ricas em compostos fenólicos.

\subsection{Análise conjunta}

As Figuras 13 e 14 representam o resumo das respostas que as plantas apresentaram nas 5 coletas realizadas durante os 150 dias de cultivo aos inúmeros fatores citados até o momento. 

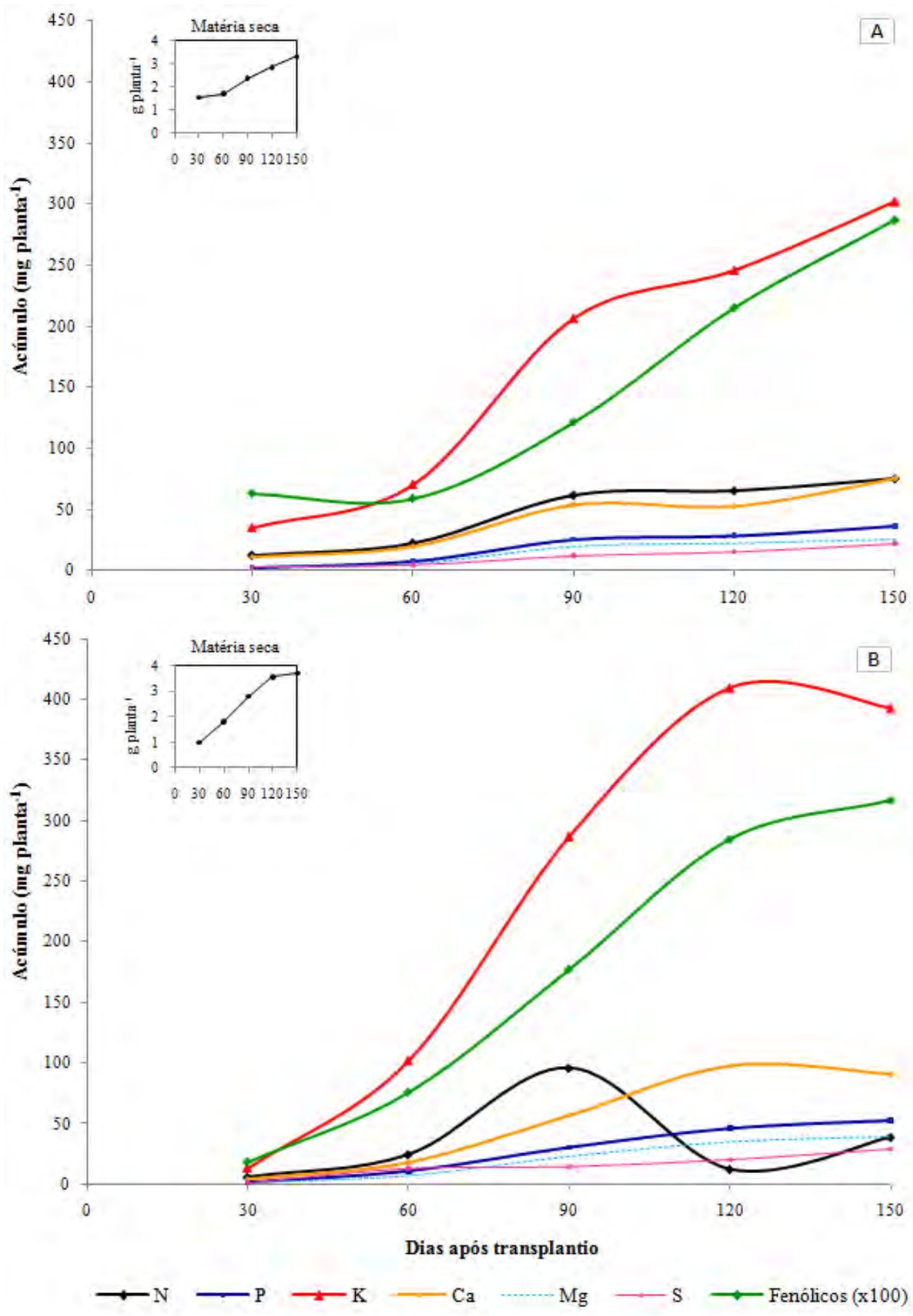

Figura 13. Acúmulo de macronutrientes e compostos fenólicos totais e produção de matéria seca em partes aéreas de plantas de carqueja var. CPQBA-1 cultivadas em vasos em casa de vegetação durante 150 dias. (A): Sem poda no transplantio; (B): Com poda no transplantio. FCF/UNESP. Araraquara, SP, 2009. 

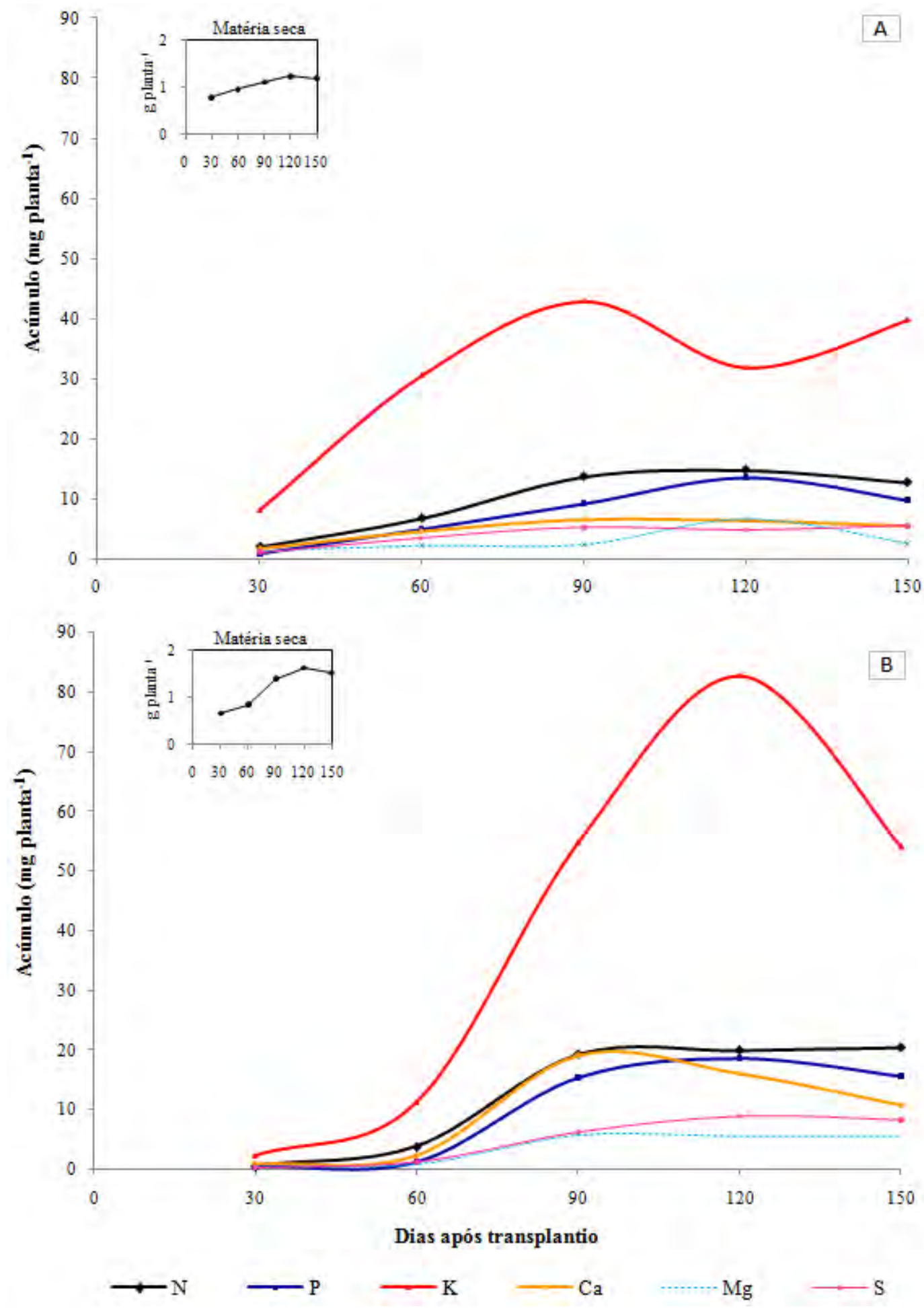

Figura 14. Acúmulo de macronutrientes e produção de matéria seca em raízes de plantas de carqueja var. CPQBA-1 cultivadas em vasos em casa de vegetação durante 150 dias. (A): Sem poda no transplantio; (B): Com poda no transplantio. FCF/UNESP. Araraquara, SP, 2009. 
A biossíntese de metabólitos secundários em plantas medicinais e, mais especificamente, da classe dos fenólicos totais depende destes inúmeros fatores resumidos em três grandes grupos: fatores genéticos, bióticos e abióticos. Neste estudo procurou-se entender, principalmente, os fatores abióticos, em que se colocou como foco as relações entre a marcha de absorção de macronutrientes e a produção de fenólicos totais.

Nota-se com maior clareza na Figura 13 uma relação direta entre a absorção dos macronutrientes e a produção de fenólicos totais, durante todo o ciclo cultivado. Já nas plantas que receberam poda no transplantio esta constatação não ficou evidente com relação ao N, o qual demonstrou queda brusca a partir dos 90 de cultivo, enquanto as plantas mantiveram a produção de fenólicos totais.

Os estudos com o intuito de entender as relações nutricionais com a produção de compostos fenólicos em plantas medicinais nativas são escassos. Malavolta (2006) cita que todos os macronutrientes possuem alguma relação direta ou indireta com o ataque de pragas e doenças; ao correlacionar esta citação, com o fato do metabolismo secundário ser fruto de mudanças evolutivas para a defesa dos vegetais (TAIZ \& ZEIGER, 2004), se verificou a necessidade de desenvolver pesquisas, a fim de elucidar as correlações entre os nutrientes, o ataque de pragas e doenças e a produção de compostos fenólicos.

Costa et al. (2007) ao estudarem a produção de flavonóides em função de diferentes adubações no cultivo fava d'anta (Dimorphandra gardneriana), notaram que a produção deste princípio ativo não variou com as adubações realizadas. O mesmo foi relatado no cultivo de fáfia (Pfaffia glomerata), realizado por Guerreiro et al. (2009), que identificaram uma produção de $\beta$-ecdisona não influenciada pelas adubações orgânicas. Já Palácio et al. (2007) ao estudarem a influência da adubação nitrogenada na produção de óleo essencial em carqueja, notaram que os teores não diferiram estatisticamente, todavia, as composições dos óleos variaram com as diferentes adubações. Estes dados reforçam a necessidade de se entender a fundo o funcionamento das rotas metabólicas secundárias e como inferir técnicas agronômicas capazes de alterá-las proporcionando aumento na produção destes compostos químicos.

Com intuito de melhorar as conclusões e recomendações técnicas, realizou-se uma análise conjunta entre os dois experimentos considerando-se as variáveis, 
produção de matéria seca da parte aérea e raízes e acúmulo de fenólicos totais, conforme mostrado na Tabela 9.

Tabela 9. Análise conjunta entre os dois experimentos, com e sem poda no dia do transplantio de carqueja var. CPQBA-1 cultivadas em vasos em casa de vegetação durante 150 dias, sem e com poda no dia de transplantio. Araraquara, SP, 2009.

\begin{tabular}{lcccccc}
\hline Variáveis & \multicolumn{2}{c}{ Com Poda } & \multicolumn{2}{c}{ Sem Poda } & Prob. > F & CV\% \\
\hline Matéria Seca - Parte aérea $^{1}$ & 6,2901 & A & 5,2078 & A & $0,36415^{*}$ & 10,62 \\
Matéria Seca - Raiz $^{1}$ & 1,7103 & A & 0,8333 & A & $0,25570^{*}$ & 18,64 \\
Fenólicos Totais $^{1}$ & 1,7456 & A & 1,4930 & A & $0,27456^{*}$ & 35,60 \\
\hline
\end{tabular}

*Não siginificativo pelo teste de $\mathrm{F}$ da análise de variância ao nível de 5\% de probabilidade.

Médias seguidas pela mesma letra maiúscula na linha não diferem entre si pelo teste Tukey ao nível de 5\% de probabilidade.

${ }^{1}$ Para os estudos estatísticos utilizou-se a transformação dos dados em $\sqrt{ } \mathrm{x}+0,3$.

A Tabela 9 demonstra que apesar de ocorrerem diferenças nas produções de matéria seca e fenólicos totais entre os tratamentos de manejo, estes não diferiram estatisticamente entre si, evidenciando que para o cultivo da variedade CPQBA-1 a poda no dia do transplantio não influencia nos resultados finais do cultivo. Sendo assim, sugere-se que novos estudos sejam realizados para elucidar melhor esta hipótese da influência do fator manejo na produção de matéria seca e fenólicos totais nesta variedade. 


\section{CONSIDERAÇÕES FINAIS}

Dentre os parâmetros avaliados durante os 150 dias de cultivo de carqueja variedade CPQBA-1, pode-se em suma destacar os seguintes pontos:

As curvas de acúmulo de matéria seca apresentaram crescimento retilíneo ascendente ao longo dos 150 dias de cultivo, demonstrando rápido crescimento entre os 60 e 120 DAT, seguido de uma estabilização do crescimento entre os 120 e 150 DAT, principalmente, nas partes aéreas. Nos últimos 30 dias de cultivo, notou-se queda na matéria seca das raízes, provavelmente, causados pelas limitações de espaço dentro dos vasos. Quanto aos dados de matéria seca aqui apresentados, pode-se inferir que para futuras pesquisas ou plantios comerciais, a colheita seja realizada próxima dos 120 dias de cultivo e para cultivo em vaso, sugere-se a utilização de vasos acima de cinco litros, quando plantadas duas plantas por vaso.

Para realização de futuros trabalhos relativos à nutrição de carqueja, sugere-se a utilização das ordens de acúmulos de macronutrientes citadas neste trabalho e que seja levado em consideração as exigências de $\mathrm{N}$ e $\mathrm{K}$ no final do ciclo da cultura, pois, infere-se que neste trabalho, as quantidade presentes no solo, tenham sido aquém das necessidades da cultura neste período. 
Esta variedade de carqueja mostrou-se menos exigente em $\mathrm{N}$ no início do cultivo e mais exigente entre os 60 e 90 DAT e no final do ciclo, quando ficou evidente a falta deste nutriente no solo, sendo recomendado para futuros trabalhos, adubações de cobertura que forneçam nitrogênio até próxima a data de colheita.

As curvas referentes aos acúmulos de $\mathrm{P}$, apesar de apresentarem teores inferiores aos teores de $\mathrm{N}$, apresentaram similaridade no decorrer dos 150 dias de cultivo, principalmente, nas partes aéreas. Em ambos os sistemas de cultivo as curvas foram ascendentes até o final do cultivo, demonstrando necessidade de um aporte incial de $\mathrm{P}$ suficiente para suprir a demanda da cultura durante todo o ciclo.

Os acúmulos de $\mathrm{K}$ superaram os demais nutrientes, mostrando maior exigência desta variedade após os 90 dias de cultivo. Evidenciando a exigência desta variedade por este nutriente até o final do ciclo, quando notavelmente, o solo mostrou-se escasso para suprir as demandas das plantas. Neste caso, sugere-se que também sejam feitas adubações de cobertura com este nutriente.

Quanto ao $\mathrm{Ca}$, as plantas absorveram este nutriente de forma ascendente durante todo o período de cultivo, apresentando valores superiores aos de $\mathrm{P}$ e muitas vezes superiores aos de $\mathrm{N}$, mostrando-se exigente por este cátion, o que evidencia a necessidade da presença deste nutriente no solo.

Esta variedade mostrou-se não muito exigente em $\mathrm{Mg}$ e $\mathrm{S}$, demonstrando os menores valores de acúmulo para ambos os nutrientes, não menos importantes em relação aos outros nutrientes. Desta forma sugere-se que novos estudos sejam realizados abordando a marcha de absorção dos micronutrientes, para que futuramente possase obter um quadro nutricional completo para esta espécie.

A produção de compostos fenólicos totais em função do tempo mostrou-se ascendente no decorrer do cultivo, sendo que as plantas que receberam poda superaram em 0,3 mg planta ${ }^{-1}$ as que não receberam. Todavia, ao se realizar a análise conjunta entre os dois tratamentos de manejo, notou-se que estes não influenciaram na produção de matéria seca e compostos fenólicos totais. Neste caso, sugere-se que não seja realizada a poda no transplantio para evitar maiores ônus ao produtor rural, contudo, propõe-se que novos estudos sejam realizados testando estes diferentes manejos, porém, analisando índices de crescimento desta espécie. 
Este trabalho se insere dentro de um contexto global da complexidade do setor de produção de plantas medicinais, que se inicia no cultivo e perdura até o objetivo final de destino da matéria-prima, a qual é dirigida a setores distintos: produção de matéria seca ou produção de princípios ativos. Destarte, depois de obtidas estas curvas de absorção de nutrientes e um perfil da produção de compostos fenólicos totais na variedade CPQBA-1, o passo seguinte para estabelecer doses de nutrientes em função do objetivo final do produto, seria a realização de novos ensaios, principalmente em nível de campo, utilizando as balizas nutricionais iniciadas com os resultados aqui obtidos. 


\section{CONCLUSÕES}

A produção de matéria seca foi ascendente durante todo o ciclo, demonstrando crescimento abundante a partir dos 90 de cultivo, seguido de estabilização nos últimos 30 dias de cultivo;

Os sistemas de manejo (com e sem poda) não influenciaram a produção de matéria seca das partes aéreas e raízes e a produção de compostos fenólicos totais;

A ordem de acúmulo de macronutrientes após 150 dias de cultivo, nas plantas que não receberam a poda no transplantio foi: $\mathrm{K}>\mathrm{N}>\mathrm{Ca}>\mathrm{P}>\mathrm{Mg}>\mathrm{S}$;

A ordem de acúmulo de macronutrientes após 150 dias de cultivo, nas plantas que receberam a poda no transplantio foi: $\mathrm{K}>\mathrm{Ca}>\mathrm{P}>\mathrm{Mg}>\mathrm{N}>\mathrm{S}$;

O potássio foi o nutriente absorvido em maiores quantidades durante os 150 dias de cultivo;

$\mathrm{O} \mathrm{Mg}$ e $\mathrm{S}$ foram os nutrientes absorvidos em menores quantidades durante os 150 dias de cultivo; 
A var. CPQBA-1 mostrou-se eficiente na translocação de todos os macronutrientes das raízes para as partes aéreas.

O acúmulo de fenólicos totais mostrou-se ascendente durante os 150 dias de cultivo, atingido o pico de produção aos 150 dias de cultivo. 


\section{REFERÊNCIAS BIBLIOGRÁFICAS}

ADAMS, R. P. Identification of essential oil components by gas cromatography/mass spectropy. Illinois: Allured Publ. Corp., 1995.469 p.

ALQUINI, Y.; TAKEMORI, N. K. Organização estrutural de espécies vegetais de interesse farmacológico. Curitiba: Herbarium Laboratório Botânico, 2000. 80 p.

ALZUGARAY, D.; ALZUGARAY, C. Enciclopédia de plantas brasileiras. São Paulo: Ed.Três, 1988. 431p.

ANDRADE, F.V.; MENDONÇA, E.S.; ALVAREZ, V.H.; NOVAIS, R.F. Adição de ácidos orgânicos e húmicos em Latossolos e adsorção de fosfato. Revista Brasileira Ciência Solo, Viçosa, 27: 1003-1011, 2003.

ANDRIÃO, M. A.; PEREIRA, F. C. S.; MARTINS, M. I. E. G.; SACRAMENTO, L.V.S. Estimativas de custo de produção e rentabilidade de plantas medicinais: carqueja cultivada em Cajuru, estado de São Paulo. Informações Econômicas. São Paulo, v.40, n.2, p.16-26, fev. 2010.

ANDRIÃO, M. A.; SACRAMENTO, L.V.S.; MARTINS, M. I. E. G.; PEREIRA, F. C. S. Desenvolvimento de planilha para cálculo de custo de produção de plantas medicinais: Baccharis trimera (Less.) DC. cultivada em propriedade rural do noroeste paulista. In: SIMPÓSIO DE PLANTAS MEDICINAIS DO BRASIL, 20.,2008, São Paulo. Resumos... 
São Paulo, 2008. p.7-7.

APPEL, H. M.; GOVENOR, H. L.; D’ASCENZO, M.; SISKA, E. SCHULTZ, J. C. Limitations of Folin assays of foliar phenolics in ecological studies. Journal of Chemical Ecology, vol. 27. n. 4, p.761-778, 2001.

BANZATTO, D. A., KRONKA, S. do N. Experimentação agrícola. Jaboticabal: Funep FCAV/UNESP, 1992. 247 p.

BARBANO, D.B.A. (Coord.). A fitoterapia no SUS e o Programa de Pesquisas de Plantas Medicinais da Central de Medicamentos. Brasília: Ministério da Saúde, 2006. 147 p.

BARBOSA FILHO, M. P. Nutrição mineral de arroz. In: Nutrição e adubação do arroz: sequeiro e irrigado. Piracicaba: Associação Brasileira para Pesquisa da Potassa e do Fosfato, 1987. p. 03-49. (Boletim técnico, 9).

BARROSO, G.M. Compositae - Subtribo Baccharidinae Hoffmann: estudo de espécies ocorrentes no Brasil. Rodriguesia, Rio de Janeiro, v.40, n.3, p.1-273, set. 1976.

BATAlHA, O.; MING, L. C. (Coord.) Plantas medicinais e aromáticas: um estudo de competitividade no Estado de São Paulo: São Carlos, SP: SEBRAE, 2003. 240 p.

BIASI, L.A.; De BONA, C.M. Propagação de Carqueja (Baccharis trimera (Less.) A.P. de Candolle) por meio de Estaquia. Revista Brasileira de Plantas Medicinais, Botucatu, v.2, n.2, p.37-43, 2000.

BORA, K.; MIGUEL, O. G; ANDRADE, C. A.; OLIVEIRA, A. O. T. de. Determinação da concentração de polifenóis e do potencial antioxidante das diferentes frações di extrato de folhas de Dicksonia sellowiana (Presl.) Hook, DICKSONIACEAE. Visão Acadêmica, Curitiba, v. 6. n.2, Jul.-Dez. 2005.

BORELLA , J.C.; FONTOURA, A.; MENEZES Jr., A.; FRANÇA, S.C. Influência da adubação mineral (N-P-K) e sazonalidade no rendimento e teor de flavonóides em indivíduos masculinos de Baccharis trimera Less. (Asteraceae) - Carqueja. Revista Brasileira de Plantas Medicinais, Botucatu, v.4, n.1, p.101-104, 2001.

BORGES SILVA, A.L.; MURAKAMI, D.M., BIZÃO, N. Origem da estaca, recipiente e composição do substrato na produção de mudas de carqueja [Baccharis trimera (Less.) DC.]. Revista Brasileira de Plantas Medicinais, Botucatu, v.10, n.4, p.97-101, 2008.

BRANDÃO, M. G. L. Carqueja. In: BRANDÃO, M. G. L. Plantas medicinais e fitoterápicos: aspectos gerais e métodos de validação. Belo Horizonte: Editora O Lutador, 2009. p.25-26.

BROWN JÚNIOR, K.S. Engenharia ecológica: perpectivas de seleção e manejo de plantas medicinais. Acta Amazônica, Manaus, v. 18, n.1/2, p. 291-303, 1988. 
CARVALHO, J.C.T.; GOSMANN, G.; SCHENKEL, E.P.; Compostos fenólicos simples e heterosídicos. In: SIMÕES, C. M. O.; SCHENKEL, E. P.; GOSMANN, G.; MELLO, J. C. P. de; MENTZ, L. A.; PETROVICK, P. R. (Orgs.). Farmacognosia da planta ao medicamento: da planta ao medicamente. Porto Alegre: Ed. Universidade UFRGS, 2007. p. 519-535.

CASTRO, H. G.; CASALI, V. W. D.; BARBOSA, L.C.A.; CECON, P. R.R Rendimento de tanino em dois acesso de carqueja (Baccharis myriocephala D. C.) em diferentes épocas de colheita em Viçosa - MG. Revista Brasileira de Plantas Medicinais, Botucatu, v.1, n.2, p.29-33, 1999.

CASTRO, H.G.; FERREIRA, F. A. Contribuição ao estudo das plantas medicinais: carqueja (Baccharis genistelloides). Viçosa: UFV, 2000. 102 p.

CASTRO, P. R. C.; KLUGE, R. A.; PERES, L. E. P. Manual de fisiologia vegetal: Teoria e Prática. Piracicaba: Editora Agronômica Ceres, 2005, 605 p.

CORDEIRO, C.H.G. Atividade biológica de gel dentifrício e enxaguatório bucal contendo extratos vegetais. Araraquara: FCF/UNESP, 2005. 98 f. Dissertação (Mestrado em Ciências Farmacêuticas)- Faculdade de Ciências Farmacêuticas, UNESP, Araraquara, 2005.

CORRÊA Jr., C; MING, L.C.; SCHEFFER, M.C. Cultivo agroecológico de plantas medicinais, aromáticas e condimentares. Brasília: Ministério do Desenvolvimento Agrário. 2006. 75 p.

CORRÊA Jr., C; MING, L.C.; SCHEFFER, M.C. Cultivo de plantas medicinais, condimentares e aromáticas. Curitiba: Emater, 1991. 162p.

CORRÊA Jr., C; MING, L.C.; SCHEFFER, M.C. Cultivo de plantas medicinais, condimentares e aromáticas. 2. ed. Jaboticabal. FUNEP, 1994. 162p.

CORTÉS, A. M. P.; BIASI, L. A.; MONTE-SERRAT, B.; NAKASHIMA, T. Extração de nutrientes pela parte aérea de carqueja sob a influência de fontes e doses de nitrogênio. Ciência Rural, Santa Maria, v. 37, n. 6, 1809-1812, 2007.

CÔRTES, C. Mercado é para poucos e bons, 1999. Folha de Londrina. Londrina, Disponível em: http://www.bonde.com.br/folha/folhad.php?id_folha=2-1--623-19991002. Acesso em: 15 dez. 2009.

COSTA, A F. Farmacognosia. 4.ed. Lisboa: Fundação Calouste Gubenkian, 1994. 1117.p. v.2.

COSTA, C.A.; ALVES, D. S.; FERNANDES, L. A.; MARTINS, E. R.; SOUZA, I. G. B.; SAMPAIO, R. A.; LOPES, P. S. do N. Nutrição mineral da fava d'anta. Horticultura Brasileira, v. 25, n. 1, jan.-mar. p. 24-28, 2007. 
De BONA, C. M. Estaquia, calagem e sombreamento de carqueja. 2002.80 f. Dissertação (Mestrado em Agronomia) - Universidade Federal do Paraná, Paraná, 2002.

De BONA, C.M.; BIASI, L.A.; ZANETTE, F.; NAKASHIMA, T. Propagação por estaquia de Baccharis articulata (Lam.) Pers., Baccharis trimera (Less.) A.P. de Candolle e Baccharis stenocephala Baker com uso de auxinas. Revista Brasileira de Plantas Medicinais, Botucatu, v.7, n.2, p.26-31, 2005a.

De BONA, C.M.; BIASI, L.A.; ZANETTE, F.; NAKASHIMA, T. Estaquia de três espécies de Baccharis. Ciência Rural, Santa Maria, v.35, n.1, p.223-226, 2005 b.

De BONA, C.M.; BIASI, L.A.; NAKASHIMA, T.; ZANETTE, F.; CORRÊA Jr., C. Carqueja: cultive esta idéia. Curitiba: SEAB-PR/UFPR, 2002. 18p.

DECHEN, A. R.; NACHTIGALL, G. R. Elementos requeridos à nutrição de plantas. In: NOVAIS, F.R.; ALVAREZ V, V. H.; BARROS, N. F. de.; FONTES, R. L. F.; CANTARUTTI, R. B.; NEVES, J. C. L. (ed.). Fertilidade do solo. Viçosa, MG: Sociedade Brasileira de Ciências do Solo, 2007. p. 91-132.

DETERMINAÇÃO de óleos essenciais em drogas vegetais. In: FARMACOPÉIA brasileira. 4. ed. São Paulo: Atheneu, 1988. pt 1, p. v.4.2.6.-v.4.2.6.-2.

DIAS, M.C.; CAMARGO, R. Estudos da adubação e propagação de carqueja. In: II WORKSHOP DE PLANTAS MEDICINAIS DE BOTUCATU, 2., 1996, Botucatu. Anais... Botucatu: UNESP, 1996. 69 p.

Di STASI, L.C. Plantas medicinais: verdades e mentiras: o que os usuários e os profissionais de saúde precisam saber. São Paulo: Editora UNESP, 2007. 133 p.

EMPRESA BRASILEIRA DE PESQUISA AGROPECUÁRIA - EMBRAPA. Centro Nacional de Pesquisa de Solo. Sistema Brasileiro de Classificação de Solos. Rio de Janeiro: Embrapa, 1999. 412 p.

FALKENBERG, M. de B.; SANTOS, R. I.; SIMÕES, C. M. O. Introdução à análise fitoquímica. In: SIMÕES, C. M. O.; SCHENKEL, E. P.; GOSMANN, G.; MELLO, J. C. P. de; MENTZ, L. A.; PETROVICK, P. R. (Orgs.). Farmacognosia da planta ao medicamento: da planta ao medicamente. Porto Alegre: Ed. Universidade UFRGS, 2007. p.229-246.

FAROOQI, A. A.; SREERAMU, B. S. History, Importance, Present Status and Future Prospects of Medicinal Crops. In: Cultivation of medicinal and aromatic crops. Hyderabad, India: Universities Press (India), 2004. p. 1-21.

FRANÇA, A. L. Natura entra no setor farmacêutico. São Paulo: Gazeta Mercantil, 2000. p. 8. (Caderno C). 
FREITAS, M.S.M.; MARTINS, M.A.; CARVALHO, A.J.C.; CARNEIRO, R.F.V. Crescimento e produção de fenóis totais em carqueja (Baccharis trimera (Less) DC.) em resposta à inoculação com fungos micorrízicos arbusculares, na presença e na ausência de adubação mineral. Revista Brasileira de Plantas Medicinais, Botucatu, v.6, n.3, p.30-34, 2004.

FURLAN, M. R. Cultivo de plantas medicinais. 3. ed. Cuiabá: SEBRAE, 2005. v. 1. 137 p.

GENÉ, R.M.; CARTAÑÁ, C.; ADZET, T.; MARÍN, E.; PARELlA, T.; CAÑIGUERAL, S. Anti-inflammatory and analgesic activity of Baccharis trimera. Identification of its active constituents. Planta Medica, v.62, n.3,p. 232-235, 1996.

GOTTLIEB, O. R.; KAPLAN, M. A. C.; BORIN, M. R. DE M. B. Biodiversidade, um enfoque químico-biológico. Rio de Janeiro: Ed. UFRJ, 1996.267p.

GRANCE, S.R.M.; TEIXEIRA, M. A.; LEITE, R.S.; GUIMARÃES, E.B.; SIQUEIRA, J. M.; FILIU, W.F. de O.; VASCONCELOS, S.B.S.; VIEIRA, M. do C. Baccharis trimera: Effect on hematological and biochemical parameters and hepatorenal evaluation in pregnant rats. Journal of Ethnopharmacology. Londres, 2008, 117. p.28-33.

GUERREIRO, C.P.V; MARQUES, M.O.M.; FERRACINI, V.L.; QUEIROZ, S.C.N.; MING, L.C. Produção de $\beta$-ecdisona em Pfaffia glomerata (Spreng.) Pedersen em função da adubação orgânica em 6 épocas de crescimento. Revista Brasileira de Plantas Medicinais, Botucatu, v.11, n.4, p.392-398, 2009.

HARBONE, J. B. Introduction to ecological biochemistry. San Diego: Academic Press, 1993, 318p.

HEIDEN, G. O gênero Baccharis L. secção Caulopterae DC. (Asteraceae) no Rio Grande do Sul. 2005. 238 f. Monografia (Graduação em Ciências Biológicas) - Universidade Federal de Pelotas, Pelotas, 2005.

HERBARIUM. O mercado de fitoterápicos no Brasil. Herbarium Saúde, Curitiba, n. 22, 2002. 2 p. Encarte.

HERMS, D.A.; MATTSON, W.J. The dilemma of plants: to grow or defend. Quaterly Review of Biology. v.67, n.3, p. 283-335, 1992.

HIROCE, R.; BENATTI JÚNIOR, R.; FUJIWARA, M.; PAULO, E. M. Marcha de absorção de nutrientes pelo rami "Miyasaki" conduzido em casa de vegetação. Bragantia. Campinas, v. 44 (2), p. 687-693, 1985.

KAMADA, T. Plasticidade fenotípica da morfologia e do óleo essencial em acessos de manjericão (Ocimum spp.) 1998. 59 f. Dissertação (Mestrado em Genética e Melhoramento)- Universidade Federal de Viçosa, Viçosa, 1998. 
LIMA FILHO, O. F. de; MALAVOLTA, E.; SENA J.O.A. de; CARNEIRO J.W.P. Absorção e acumulação de nutrientes em estévia Stevia rebaudiana (Bert.) Bertoni: I. Macronutrientes. Scientia Agricola. Piracicaba, vol. 54 n. 1-2, Jan./Aug. 1997.

LORENZI, H. Plantas daninhas do Brasil: terrestres, aquáticas, parasitas e tóxicas. Nova Odessa: Instituto Plantarum, 2000. 608p.

LORENZI, H.; MATOS, F. J. de A. de. Plantas medicinais no Brasil: nativas e exóticas. Nova Odessa: Instituto Plantarum de Estudos da Flora, 2002. 512p.

LOURENZANI, A.E.B.S.; LOURENZANI, W.L.; BATALHA, M.O. Barreiras e oportunidades na comercialização de plantas medicinais provenientes da agricultura familiar. CUSTAGRI. Informações Econômicas, São Paulo, v. 34, n. 3, p. 15-25, mar. 2004.

MALAVOLTA, E. Elementos de nutrição mineral de plantas. São Paulo: Ed. Agronômica Ceres, 1980. 251p.

MALAVOLTA, E. Manual de nutrição mineral de plantas. São Paulo: Ed. Agronômica Ceres, 2006. 631p.

MALAVOLTA, E.; VITTI, G.C.; OLIVEIRA, S.A. de. Avaliação do estado nutricional das plantas: princípios e aplicações. 2 ed. Piracicaba: Associação Brasileira para a Pesquisa da Potassa e do Fosfato, 1997. 319p.

MALAVOLTA, E. FORNASIERI FILHO, D. Nutrição mineral da cultura do arroz. In: FERREIRA, M. E. et al. (Ed). Cultura do arroz de sequeiro: fatores afetando a produtividade. Piracicaba: Instituto de Potassa \& Fosfato: Instituto Internacional da Potassa, 1983. p. $95-140$.

MARCUSSI, F. F. N. Uso da fertirrigação e teores de macronutrientes em planta de pimentão. Revista Engenharia Agrícola, Jaboticabal, v.25, n.3, p.642-650, set./dez. 2005.

MARQUES, L.C. Avaliação de drogas vegetais no Paraná. In: SIMPÓSIO DE PLANTAS MEDICINAIS DO BRASIL, 10. Resumos... João Pessoa, 1990.

MARQUES, L.C. et al. Problemas na identificação de espécies vegetais usadas como matéria prima na indústria de fitoterápicos no Paraná. In: SIMPÓSIO DE PLANTAS MEDICINAIS DO BRASIL, 12. Resumos... Curitiba, 1992.

MARTINS, E. R.; CASTRO, D. M.; CASTELLANI, D.C.; DIAS J. E. Plantas Medicinais. Viçosa: UFV, 1995. 220p.

McCONCHIE, R.; LANG, N. S.; LAX, A. R.; LANG, G. A. Reexamining polyphenol oxidase, peroxidase, and leaf-blackening activity in Protea. Journal of the American Society for Horticultural Science. Palo Alto, v.119, n.6, p.1248-54, 1994. 
MCLAFFERTY, F.W., STAUFFER, D. The Wiley/NBS registry of mass spectral data. v. 1-6, New York: John Wiley \& Sons, 1989.

MENDES, F.R.; TABACH, R. CARLINI, E.A. Evaluation of Baccharis trimera and Davilla rugosa in Tests for Adaptogen Activity. Phytotherapy Research. 2007. 21, p.517-522.

MENEZES Jr., A. Aspectos Agronômicos Básicos em Fitoterapia. In: FERRO, D. Fitoterapia: conceitos clínicos. São Paulo: Atheneu, 2006. p.67-82.

MOL, D. J. S.; SILVA, F.G.; PINTO, J. E. B. P.; CARDOSO, M. G.; NASCIMENTO, B.E.; BERTOLUCCI, S.K.V. Acúmulo da biomassa e rendimento do óleo essencial de carqueja em função do sistema de manejo e alturas de poda. In: CONGRESSO BRASILEIRO DE OLERICULTURA, 42., 2002, Uberlândia , MG, 2002. Anais... Horticultura Brasileira, Campinas, v.20, n. 2, 2002. supl. CD-ROM.

NAIVERTH, J. A.; FARIA, C. M. D. R. Cultivo de plantas medicinais como alternativa de renda para agricultores familiares do município de Candói-PR. Revista Eletrônica Lato Sensu, Guarapuava, n.4, 2007. Disponível em: < http://web03.unicentro.br/especializacao/Revista_Pos/P\%C3\%A1ginas/2\%20Edi\%C3\%A7\%C 3\%A3o/Agrarias/PDF/4-Ed2_CA-Cultivo.pdf. Acesso: 15 dez. 2009.

NAKASUGI, T.; KOMAI, K. Antimutagens in the brazilian folk medicinal plant Carqueja (Baccharis trimera Less.). Journal of Agricultural Food Chemistry. Washington, v.46, p.2560-2564, 1998.

NOGUEIRA, M.C.S. Curso de estatística experimental aplicada à experimentação agronômica. Piracicaba: USP-ESALQ, 1991. 197p. (mimeogr.)

OLIVEIRA, A.C.P.; ENDRINGER, D.C; AMORIM, L.A.S, BRANDÃO, M.G.L.; COELHO, M.M. Effect of the extracts and fractions of Baccharis trimera and Syzygium cumini on glycaemia of diabetic and non-diabetic mice. Journal of Ethnopharmacol. Londres, 2005, v.102, p. 465-469, 2005.

OLIVEIRA, F.; AKISUE, G. Fundamentos de farmacobotânica. 2. ed. São Paulo: Atheneu, 1997. 178p.

OLIVEIRA, L.N.P.; MORESCO, P.M.M. Verde saúde Curitiba: plantas medicinais. Curitiba: Prefeitura Municipal de Curitiba, 1999. 60 p.

PALÁCIO, C.P.A.M.; BIASI, L.A.; NAKASHIMA, T.; SERRAT, B.M. Biomassa e óleo essencial de carqueja (Baccharis trimera (Less) DC.) sob influência de fontes e doses de nitrogênio. Rev. Bras. Plantas Med., Botucatu, v.9, n.3, p.58-63, 2007.

PAVAN-FRUEHAUF, S. Plantas medicinais de mata atlântica: manejo sustentado e amostragem. São Paulo: Annablume/Fapesp, 2000. 216p. 
PEREIRA FILHO, J. Cresce o espaço das plantas na medicina. Gazeta Mercantil, São Paulo, 11-17 abr. 2001. Por conta própria, p. 8-9.

PHARMACOPEIA DOS ESTADOS UNIDOS DO BRASIL. São Paulo: Companhia Editora Nacional, 1929.

PIMENTEL-GOMES, F.; GARCIA, C. H. Estatística aplicada a experimentos agronômicos e florestais: exposição com exemplos e orientações para uso aplicativos. Piracicaba: FEALQ, 2002. 309 p.

POCÁ, A. M. P. C. Biomassa, óleo essencial, perfil fitoquímico e nutrientes da carqueja sob influência de fatores e doses de nitrogênio. 2005. 59f. Curitiba: Dissertação (Mestrado em Ciências)- Universidade Federal do Paraná, Paraná, 2005.

PRIMAVESI, A. Manejo ecológico do solo: A agricultura em regiões tropicais. São Paulo: Nobel, 2002, 549 p.

RAIJ, B. Van.; CANTARELLA, H.; QUAGGIO, J. A.; FURLANI, A. M. C. Recomendações de adubação e calagem para o Estado de São Paulo. 2. ed. Campinas: Instituto Agronômico, Fundação IAC, 1997. 285 p. (Boletim Técnico, 100)

REIS, M. S.; MARIOT, A.; STEENBOCK, W. Diversidade e domesticação de plantas medicinais. In: SIMÕES, C. M. O.; SCHENKEL, E. P.; GOSMANN, G.; MELLO, J. C. P. de; MENTZ, L. A.; PETROVICK, P. R. (Orgs.). Farmacognosia da planta ao medicamento: da planta ao medicamento. Porto Alegre: Ed. Universidade UFRGS, 2007. p.45-74.

REIS, M. S.; MARIOT, A. Manejo de populações naturais de plantas medicinais em Santa Catarina. In: JORNADA CATARINENSE DE PLANTAS MEDICINAIS, 1., 1998, Tubarão. Ata. Tubarão: UNISUL - Universidade do Sul de Santa Catarina, 1998. p. 83-90.

ROSA, Z.M. Compostas medicinais. Natureza em Revista, 1989. p.32-37.

ROSOLEM, C. A. Nutrição e adubação do feijoeiro. Piracicaba: Associação Brasileira para Pesquisa da Potassa e do Fosfato, 1987. 93 p. (Boletim técnico, 8).

SÁ, M.F.A. Estudo anatômico e ensaios fitoquímicos de Baccharis myriocephala D.L. carqueja. Rio de Janeiro: UFRJ, 1992. 91 p. Dissertação (Mestrado em Botânica) Universidade Federal do Rio de Janeiro, Rio de Janeiro, 1992.

SACRAMENTO, L.V.S.; APPEZZATO-DA-GLORIA, B. Depósito de cera epicuticular anômalo em exsicatas de Baccharis trimera e síntese de compostos fenólicos associada à infecção fúngica. In: $7^{\mathbf{0}}$ Simpósio Brasileiro de Farmacognosia, 2009, Maringá - PR. CDROM, 2009. 
SANTOS, C.A.M.; TORRES. K.R.; LEONART, R. Plantas medicinais: herbarium flora et scientia. 2. ed. São Paulo: Ícone, 1988. 160p.

SANTOS, R. I. Metabolismo básico e origem dos metabólitos secundários. In: SIMÕES, C. M. O.; SCHENKEL, E. P.; GOSMANN, G.; MELlO, J. C. P. de; MENTZ, L. A.; PETROVICK, P. R. (Orgs.). Farmacognosia da planta ao medicamento: da planta ao medicamente. Porto Alegre: Ed. Universidade UFRGS, 2007. p. 403-434.

SARIKAYA, A. O.; ULUSOY, E.; OZTURK, N. TUNÇEL, M.; KOLAYLI, S. Antioxidant activity and phenolic acid constituints of chestnut (Castania sativa Mill.) honey and propolis. Journal of Food Biochemistry. v.33, p.470-481, 2009.

SCHEFFER, M. C.; CORREA Jr., C.; GRAÇA, L. R. Transformação e comercialização de plantas medicinais, condimentares e aromáticas no estado do Paraná. In: CORRÊA JUNIOR, C.; GRAÇA, L. R.; SCHEFFER, M. C. Complexo agroindustrial das plantas medicinais, aromáticas e condimentares no estado do Paraná - Diagnósticos e Perspectivas. Curitiba: Soc. Paranaense de Plantas Medicinais: EMATER - PR: [Colombo]: Embrapa Florestas, 2004. p. 95-163.

SCHULZ, V.; HANSEL, R.; TYLER, V. E. Fitoterapia racional. 4. ed. Barueri-SP: Manole, 2002. $365 \mathrm{p}$.

SILVA, F.G.; JANUÁRIO, A.H.; PINTO, J. E. B. P.; NASCIMENTO, V.E. BARIZAN, W.S.; SALES, J.F.; FRANÇA, S.C. Teor de flavonóides em populações silvestres e cultivadas de carqueja (Baccharis trimera (Less.) DC.) coletadas nas estações seca e úmida. Revista Brasileira de Plantas Medicinais, Botucatu, v.8, n.2, p.19-25, 2006.

SILVA, F.G.; PINTO, J. E. B. P.; NASCIMENTO, V.E.; SALES, J.F.; SOUCHIE, E.L.; BERTOLUCCI, S.K.V. Seasonal variation in the total phenol contents in cultivated and wild carqueja (Baccharis trimera (Less) DC.). Revista Brasileira de Plantas Medicinais, Botucatu, v.9, n.3, p.52-57, 2007.

SILVA, F. G. Teor de fenóis, flavonóides e óleos essenciais em calos, plântulas e plantas em caqueja [Baccharis trimera (Less) D.C. ASTERACEAE]. 2005. 133 f. Tese (Doutorado em Agronomia / Fitotecnia)-Universidade Federal de Lavras, Lavras, 2005.

SILVA JÚNIOR, A.A. Plantas medicinais e aromáticas. Itajaí: Epagri, 1997. (CD-ROM).

SIMÕES, C.M.O.; MENTZ, L.A.; SCHENKEL, E.P.; IRGANG, B. E.; STEHMANN, J.R. Plantas da medicina popular no Rio Grande do Sul. 5. ed. Porto Alegre: Ed. Universidade/UFRGS, 1998. 173p.

SINGLETON, V. L.; ORTHOFER, R.; LAMUELA-RAVENTÓS, R. M. Analysis of Total Phenols and Other oxidation Substrates and Antioxidants by Means of Folin-Ciocalteu Reagent. Methods in Enzymology. Nova York, v.299, p. 152-178, 1999. 
SINGLETON, V. L.; ROSSI, J. A. Jr. M. Colorimetry of Total Phenolics with Phosphomolybdic-Phosphotungstic Acid Reagents. American Journal of Enology and Viticulture. Davis, v.16, p. 144-158. 1965.

SOICKE, H.; LENG-PESCHLOW, E. Characterization of flavonoids from Baccharis trimera and their antihepatotoxic properties. Planta Medica., v.53, p.37-39, 1987.

SOUSA, C. M. de M. et al. FENÓIS TOTAIS E ATIVIDADE ANTIOXIDANTE DE CINCO PLANTAS MEDICINAIS. Química Nova. São Paulo. Vol. 30, No. 2, 351-355, 2007.

SOUSA, L. A. Produtividade e nutrição em três acessos de Baccharis trimera em função da adubação organo-mineral, em casa de vegetação. 2005.42f. Dissertação Dissertação (Mestrado em Agronomia) - Faculdade de Ciências Agronômicas, UNESP, Botucatu, 2005.

SOUSA, L. A.; SACRAMENTO, L. V. S.; MING, L. C.; Propagação em três acessos de Baccharis trimera em fenofase reprodutiva. Revista Brasileira de Plantas Medicinais, Botucatu, v.8, n.4, p.189-192, 2006.

SOUZA, V. C.; LORENZI, H. Asteraceae (compositae). In: Botânica sistemática: guia ilustrado para identificação das famílias de Angiospermas da flora brasileira, baseado em APG II. Nova Odessa: Instituto Plantarum, 2005. p. 572-601.

TAIZ, L.; ZEIGER, E. Metabólitos secundários e defesa vegetal. In: Fisiologia vegetal. 3. ed. Porto Alegre, RS: ARTMED, 2004. p. 309-334.

TRANI, P. E.; PASSOS, F. A.; MELO, A.M.T.; TIVELLI, S.W.; BOVI, O. A.; PIMENTEL, E. C. Intruções técnicas para 41 espécies de plantas medicinais. In: . Hortaliças e plantas medicinais: manual prático. Campinas: Instituto Agronômico, 2007. p.45-47.

VIEIRA, R. F.; SILVA, S. R. (Orgs.). Estratégias para conservação e manejo de recursos genéticos de plantas medicinais e aromáticas: resultados da $1^{a}$ Reunião Técnica. Brasília: Embrapa/Ibama/MMA/CNPq, 2002.184 p.

WORLD HEALTH ORGANIZATION. Guidelines for appropriate use of herbal medicine. WHO Regional Publication, Western Pacific Series, v.23, 79p. 1998. Disponível em: http://www.whjo.int/en/. Acesso em: 08 out. 2009. 